\title{
Widespread evidence for high-temperature formation of pentlandite in chondrites
}

\author{
Devin L. Schrader ${ }^{1 * \dagger}$, Jemma Davidson ${ }^{2}$, and Timothy J. McCoy ${ }^{1}$ \\ ${ }^{1}$ Department of Mineral Sciences, National Museum of Natural History, Smithsonian \\ Institution, $10^{\text {th }}$ \& Constitution Avenue NW, Washington, D.C. 20560-0119, USA \\ ${ }^{2}$ Department of Terrestrial Magnetism, Carnegie Institution of Washington, 5241 Broad \\ Branch Road NW, Washington, DC 20015-1305, USA
}

For submission to Geochimica et Cosmochimica Acta

December $9^{\text {th }}, 2015$

Resubmitted May $27^{\text {th }}, 2016$

*Corresponding author: Devin L. Schrader $\dagger$ Present Address:

Phone: 480-965-0720

Email: schraderd@asu.edu

Center for Meteorite Studies

School of Earth and Space Exploration

Arizona State University

P.O. Box 871404

Tempe AZ 85287, USA

Words: 7412 in main text

Figures: 5 (and three Electronic Annexes)

Tables: 4

Key Words: pentlandite, pyrrhotite, exsolution, high-temperature, annealing, aqueous alteration 


\begin{abstract}
By investigating the compositional and textural evolution of sulfides within a wide range of relatively pristine, aqueously altered, and thermally metamorphosed chondrites we constrain the equilibration temperatures of sulfide minerals and compare them to the metamorphic history of their host meteorite. Sulfides in Mighei-like carbonaceous chondrites are complex as they equilibrated mostly between 100 and $135^{\circ} \mathrm{C}$, but some may have equilibrated at temperatures up to $600^{\circ} \mathrm{C}$. This is consistent with some $\mathrm{CM}$ chondrite sulfides forming at high temperature during chondrule cooling and others during low-temperature aqueous alteration and/or annealing. Karoonda-like carbonaceous chondrite sulfides equilibrated between 500 and $230^{\circ} \mathrm{C}$, which is consistent with formation during cooling and annealing after thermal metamorphism. Sulfides in the LL chondrites equilibrated between 600 and $230^{\circ} \mathrm{C}$, and are consistent with formation during chondrule cooling for Semarkona (LL3.00) and during cooling after thermal metamorphism for the equilibrated samples (types 4-6). Sulfides in the Rumuruti-like (R) chondrites equilibrated between 600 and $500^{\circ} \mathrm{C}$, and are consistent with formation after thermal metamorphism. The sulfides within the brachinite equilibrated between 600 and $400^{\circ} \mathrm{C}$, consistent with formation during cooling after thermal metamorphism.

Contrary to the assertion that pentlandite is solely the product of low-temperature aqueous alteration in many chondrite groups, this study suggests that most sulfides in chondrites are formed at or upon cooling from high-temperature. The evaluation of a single mineral system within samples that retain petrographic context is vital to the interpretation of formation and alteration processes recorded by small extraterrestrial samples, such as those that have been returned by the spacecraft missions Stardust and Hayabusa and will be returned by OSIRIS-REx and Hayabusa2.
\end{abstract}




\section{INTRODUCTION}

As the $10^{\text {th }}$ most abundant element in the Solar System, sulfur is a major rockforming element in terrestrial and early Solar System materials (e.g., Brearley, 2006; Vaughan, 2006; Lodders et al., 2009; Dare et al., 2010; Schrader et al., 2015a). Sulfur is a volatile element that exhibits chalcophile behavior. Sulfides are present in returned samples and a wide range of meteorites with varied metamorphic histories. These include pristine material nearly unaltered since asteroid accretion (e.g., Davidson et al., 2014a; Schrader et al., 2015a), aqueously altered and thermally metamorphosed extraterrestrial materials (e.g., Geiger and Bischoff, 1995; Zolensky and Thomas, 1995; Bullock et al., 2005; Rubin, 2006; Righter and Neff, 2007; Zolensky et al., 2008; Kimura et al., 2011; Harries and Langenhorst, 2013), and partially and fully differentiated meteorites (e.g., McCoy et al., 2006; Schrader et al., 2010a; Gardner-Vandy et al., 2013). Sulfides have been identified in both Stardust and Hayabusa returned samples (e.g., Zolensky et al., 2008; Berger et al., 2011; Nakamura et al., 2011). The most abundant sulfides in extraterrestrial samples are the pyrrhotite group sulfides troilite $[\mathrm{FeS}]$ and pyrrhotite $\left[(\mathrm{Fe}, \mathrm{Ni}, \mathrm{Co}, \mathrm{Cr})_{1-\mathrm{x}} \mathrm{S}\right]$, which can occur in combination with other sulfides, such as pentlandite $\left[(\mathrm{Fe}, \mathrm{Ni}, \mathrm{Co}, \mathrm{Cr})_{9-\mathrm{x}} \mathrm{S}_{8}\right]$, pyrite $\left[\mathrm{FeS}_{2}\right]$, and chalcopyrite $\left[\mathrm{CuFeS}_{2}\right]$.

Pyrrhotite and pentlandite can form over a range of conditions, via both high- and low-temperature processes, which are recorded by their compositions. Experimental petrologists have determined that the composition of pentlandite varies with equilibration temperature, and constructed equilibrium phase diagrams at a range of temperatures in the Fe-Ni-S system (e.g., Kullerud, 1963a; Kullerud et al., 1969; Misra and Fleet, 1973; Francis et al., 1976; Naldrett, 1989; Karup-Moeller and Makovicky, 1995; Sugaki and Kitakaze, 1998; Etschmann et al., 2004; Raghavan, 2004a). The composition of sulfides, in comparison to these diagrams, can be used to constrain equilibration temperatures. Pyrrhotite-pentlandite intergrowths can form via multiple mechanisms: (1) aqueous alteration (e.g., Brearley, 2006), (2) cooling of a primary high-temperature Ni-rich Fe-Ni$\mathrm{S}$ melt with crystallization of monosulfide solid solution (mss) at $\sim 950^{\circ} \mathrm{C}(\mathrm{Fe}, \mathrm{Ni}-\mathrm{FeS}$

eutectic; Kullerud, 1963b; McCoy et al., 2006) followed by pentlandite exsolution starting at $\sim 610^{\circ} \mathrm{C}$, (3) thermal metamorphism of an $\mathrm{Fe}-\mathrm{Ni}-\mathrm{S}$ assemblage $>610^{\circ} \mathrm{C}$ and 
subsequent cooling, (4) annealing between $\sim 600$ and $200^{\circ} \mathrm{C}$ (e.g., Kullerud, 1963a; Misra and Fleet, 1973; Francis et al., 1976; Etschmann et al., 2004), and (5) gas-solid sulfurization (Lauretta et al., 1998). If the $\mathrm{Ni}$ content of a sulfide is too low, pentlandite does not form and instead Ni remains in pyrrhotite.

In extraterrestrial samples, pentlandite formation has been attributed to parent body low-temperature metamorphism and/or aqueous alteration, as suggested for the Ivuna-like (CI), Mighei-like (CM), Renazzo-like (CR), and Vigarano-like (CV) carbonaceous chondrites, the LL3.00 ordinary chondrite (OC) Semarkona, and returned samples from comet 81P/Wild 2 (e.g., Zolensky and Thomas, 1995; Bullock et al., 2005; Brearley, 2006; Rubin, 2006; Zolensky et al., 2008; Berger et al., 2011; Kimura et al., 2011; Harries and Langenhorst, 2013). The composition of pyrrhotite and pentlandite within the CI chondrites are consistent with formation during aqueous alteration between 100 and $135^{\circ} \mathrm{C}$ (Bullock et al., 2005). Furthermore, pentlandite is present in hydrous interplanetary dust particles (IDPs) but absent from anhydrous IDPs, which contain troilite and pyrrhotite, suggesting that pentlandite was an aqueous-alteration product (Zolensky and Thomas, 1995).

In contrast, experimental petrologists have shown that pentlandite can form through alternative pathways. The cooling of high-temperature Fe-Ni-S melts results in pentlandite formation via exsolution below $610^{\circ} \mathrm{C}$ during the breakdown of crystallized mss into pentlandite and pyrrhotite (e.g., Kullerud, 1963a; Francis et al., 1976; Kelly and Vaughn, 1983; Etschmann et al., 2004). When cooling from a melt, mss crystallizes at $\sim 950^{\circ} \mathrm{C}$ and then pentlandite exsolution commences at $\sim 610$ to $550^{\circ} \mathrm{C}$ and completes at $\sim 325$ to $275^{\circ} \mathrm{C}$ (Kullerud, 1963a; Francis et al., 1976; Etschmann et al., 2004). Upon heating a solidified sulfide containing pentlandite and pyrrhotite, pentlandite dissolves back into mss above $\sim 610^{\circ} \mathrm{C}$ and re-exsolves during cooling below $610^{\circ} \mathrm{C}$. Annealing/quench experiments result in rapid ( $\sim \mathrm{hr})$ initial exsolution of pentlandite at 500 to $230^{\circ} \mathrm{C}$ (Misra and Fleet, 1973; Etschmann et al., 2004), however not all Ni partitioned into pentlandite and pyrrhotite remained Ni-rich ( 17 at.\% Ni) after months at constant temperature, indicating the formation of intergrowths of pentlandite and Ni-poor pyrrhotite by annealing requires much longer timescales (Etschmann et al., 2004). Alternatively, pentlandite has also been shown to form as a result of gas-solid kamacite 
sulfurization experiments between $\sim 285$ and $370^{\circ} \mathrm{C}$ over one month duration (Lauretta et al., 1998).

The anhydrous formation mechanisms discussed above produce three general textures of pyrrhotite-pentlandite intergrowths (Figs. 1 and 2): (1) pentlandite rims around pyrrhotite; (2) blocky pentlandite, which sometimes contain 'islands' of pyrrhotite; and (3) blebs or 'stringers' (often termed flame or brush texture) of pentlandite within pyrrhotite (e.g., Newhouse, 1927; Hewitt, 1938; Hawley and Haw, 1957; Francis et al., 1976; Etschmann et al., 2004; Dare et al., 2010). Rapid cooling (quench) results in randomly oriented pentlandite blebs in pyrrhotite, while slower cooling results in oriented blebs and pentlandite lamellae (Francis et al., 1976; Etschmann et al., 2004). In terrestrial magmatic sulfide ore deposits, pyrrhotite and pentlandite are often associated with chalcopyrite and pyrite (Naldrett et al., 1967; Keays et al., 1981; Dare et al., 2010) and sometimes with Co-rich pentlandite (Merkle and Gruenewaldt, 1986).

Recent studies of sulfides in chondrites indicate that not all pentlandite formed via aqueous alteration. Observations of pyrrhotite-pentlandite intergrowths in the CR and CM chondrites suggest that they are primary high-temperature products (preaccretionary) that formed during crystallization and exsolution below silicate solidus temperatures (Schrader et al., 2010b; 2014; 2015a; 2015b; Singerling and Brearley, 2014; 2015). However, it has also been suggested that pentlandite in CM chondrites exsolved from mss after low- and high-temperature parent body thermal metamorphism (Brearley and Martinez, 2010; Kimura et al., 2011), and formed by gas-solid interactions prior to accretion (Harries and Langenhorst, 2013). In addition, blocky pentlandite in the LLimpact melt Northwest Africa 4859 is attributed to low-temperature annealing $\left(<230^{\circ} \mathrm{C}\right)$ after impact heating (Jamsja and Ruzicka, 2010), while pentlandite in CV chondrite metamorphosed clasts were determined to have exsolved at high temperature $\left(\sim 600^{\circ} \mathrm{C}\right.$; Jogo et al., 2012).

To critically evaluate the formation conditions of pentlandite within meteorites, we investigated pentlandite and associated sulfides from meteorites covering a wide range of aqueous and thermal histories; including CM, Karoonda-like carbonaceous (CK), LL and Rumuruti-like (R) chondrites, and a brachinite. The evaluation of a single mineral system within samples that retain petrographic context is vital to interpreting formation and 
alteration processes recorded by small extraterrestrial samples, such as those that have been returned by the spacecraft missions Stardust and Hayabusa and will be returned by OSIRIS-REx and Hayabusa2.

\section{ANALYTICAL PROCEDURE}

\subsection{Mineralogy and Petrology}

Sulfides and silicates in thin sections of 16 meteorites were studied: Mighei USNM3483-3 (CM2), Sutter's Mill (C, CM-like), ALH 85002,87 (CK4), Karoonda USNM2428-3 (CK4), LAR 06868 (CK5), and LEW 87009 (CK6), Semarkona USNM1805-17 (LL3.00), Soko-Banja USNM3078-1 (LL4), Siena USNM3070-3 (LL5), Saint-Séverin USNM2608-3 (LL6), MET 01149,27 (R3), LAP 03639,2 (R4), LAP 031275,2 (R5), LAP 04840,4 (R6), MIL 11207,2 (R6), and EET 99402,6 (brachinite) (Table 1). To minimize the effects of terrestrial weathering, falls and minimally weathered Antarctic meteorites were selected whenever possible. Thin sections were initially characterized using an optical microscope to identify sulfides. Backscatter electron (BSE) images and mineral identification via energy dispersive X-ray spectroscopy (EDS) were conducted on an FEI Nova NanoSEM 600 scanning electron microscope (SEM) at the Smithsonian Institution (SI) National Museum of Natural History, Department of Mineral Sciences.

The major element compositions of sulfides, metals, low-calcium pyroxene (LCP), and high-calcium pyroxene (HCP) were measured with a JEOL 8900 Superprobe electron probe microanalyzer (EPMA) at SI. Polished and carbon-coated thin sections were analyzed with a focused beam as individual points and line scans, with operating conditions of $15 \mathrm{kV}$ and $20 \mathrm{nA}$, and a ZAF correction method (a Phi-Rho-Z correction technique; Armstrong 1988); peak and background counting times were varied per element to optimize detection limits. Only sulfide and metal analyses with totals between 97.5-102.5 wt.\%, and stoichiometric silicate analyses with totals between 98.0-102.0 wt.\% were retained. Standards and detection limits are listed in Tables 2 and 3. 


\subsection{Closure temperatures and oxygen fugacities}

Minimum temperatures of thermal metamorphism were previously estimated via diffusion-driven geothermometers (e.g., graphite ordering, and olivine-chromite and twopyroxene equilibration) in the literature (Table 1) for many samples in this study. For those without prior temperatures constraints, and to enable direct comparison to literature data, closure temperatures were calculated for thermally metamorphosed and equilibrated samples using the two-pyroxene geothermometer when suitable mineral pairs were present (Tables 1 and 3). Two-pyroxene equilibration temperatures were determined using the compositions of co-existing LCP and HCP mineral pairs with the QUILF program (Anderson et al., 1993). Each temperature was determined at a pressure estimate of 1 bar; which is a reasonable approximation for an asteroid (e.g., Benedix et al., 2005; Gardner-Vandy et al., 2013). Proper pyroxene projections were computed using QUILF by considering both major and minor element compositions (e.g., Lindsley, 1983) for each pyroxene pair (i.e., coexisting LCP and HCP). Uncertainties on temperatures are determined for each mineral pair by QUILF for two-pyroxene temperatures (from $\pm 25^{\circ} \mathrm{C}$ to $\pm 194^{\circ} \mathrm{C}, 1 \sigma$ ). Multiple mineral pairs (5 to 10 ) and corresponding temperatures were obtained per sample; suitable mineral pairs were obtained in both chondrules and matrix. Since individual two-pyroxene temperatures were within $2 \sigma$ for each sample, weighted means using all calculated temperatures were determined to obtain a single temperature for each sample and minimize uncertainties (Table 1).

The corresponding oxygen fugacity $\left(f \mathrm{O}_{2}\right)$ for Siena and Saint-Séverin were calculated at the appropriate weighted mean two-pyroxene closure temperature because specific $f \mathrm{O}_{2}$ values were not available. The $\mathrm{fO}_{2} \mathrm{~s}$ were determined from the quartz-iron-ferrosilite buffer reaction (QIFs). The reaction equation is:

$$
2 \mathrm{Fe}+2 \mathrm{SiO}_{2}+\mathrm{O}_{2}(\mathrm{~g})=2 \mathrm{FeSiO}_{3}
$$

The $\mathrm{fO}_{2}$ for each reaction is determined via the following equation (for simplicity, $\mathrm{FeSiO}_{3}$ is expressed as Fs): 


$$
\log \left(f \mathrm{O}_{2}\right)=2 \log \left(\mathrm{a}_{\mathrm{Fs}}\right)-\log \mathrm{K}-2 \log \left(\mathrm{a}_{\mathrm{Fe}}\right)-2 \log \left(\mathrm{a}_{\mathrm{SiO} 2}\right)
$$

The online MELTS calculator (http://melts.ofm-research.org/CalcForms/index.html) was used to obtain the activity of ferrosilite $\left(\mathrm{a}_{\mathrm{Fs}}\right)$ (Sack and Ghiorso, 1989; Hirschmann, 1991). The Fe content of Fe,Ni-metal was used to obtain the Fe activity $\left(\mathrm{a}_{\mathrm{Fe}}\right)\left(\right.$ Siena, $\mathrm{a}_{\mathrm{Fe}}=0.47$; Saint-Séverin, $\left.\mathrm{a}_{\mathrm{Fe}}=0.72\right)$. Following Benedix et al. (2005), we assume a silica activity $\left(a_{\mathrm{SiO} 2}\right)$ of 0.9 for the three-component system metal-olivine-LCP. The HSC 7.0 Chemistry Reaction Equation module was used to obtain the temperature dependent equilibrium constant (K) at 1 bar. Oxygen fugacities are then referenced to the iron-wüstite (IW) buffer, which was also determined using HSC Chemistry.

\section{RESULTS}

\subsection{Sulfide composition, morphology, and associated minerals}

Analyses of major and minor elements were performed on pyrrhotite/troilite/pyrite (495 analyses), pentlandite (439 analyses), Fe,Ni-metal (9 analyses), Co-rich pentlandite (7 analyses), chalcopyrite (5 analyses), and Cu-rich sulfide (1.7-9.7 wt.\% $\mathrm{Cu} ; 2$ analyses) (Tables 2 and 4). While some analyses indicate the sulfides are troilite, they also contain minor elements (e.g., $\mathrm{Ni}, \mathrm{Co}, \mathrm{Cr}$, and $\mathrm{Cu}$ ). For ease of communication, pyrrhotite and troilite, both members of the pyrrhotite group of sulfides, will be collectively referred to as pyrrhotite. The vast majority of data was collected on phase pure grains. However, some of the nearly continuous range in $\mathrm{Ni}$ content between pyrrhotite and pentlandite is likely due to beam overlap; pentlandite is determined in Section 4.2 to have $\geq 16 \mathrm{wt} . \% \mathrm{Ni}$ (Fig. 3, and Tables 2 and 4; Schrader et al., 2015a). Due to the presence of sub-micron size grains of pentlandite in pyrrhotite, sulfide analyses in the $\mathrm{CM}$ and $\mathrm{R}$ chondrites may include some analyses with beam overlaps. In contrast, beam overlaps in the brachinite, and the LL and CK chondrites are less likely as sulfide analyses were conducted on phase pure pentlandite grains larger than the interaction volume of the EPMA beam (Figs. 1 and 2, and Electronic Annex [EA]-1). 
In thermally metamorphosed samples, analyses of LCP and HCP (Table 3) were obtained to facilitate two-pyroxene thermometry and $\mathrm{fO}_{2}$ calculations.

\subsubsection{CM chondrites}

Pentlandite (22.2-34.0 wt.\% Ni) is common in the CM chondrites and is present as blocky grains, lamellae, and oriented blebs (e.g., Fig. 1a and EA-1) within pyrrhotite (0.26-9.7 wt.\% Ni; Fig. 3 and Table 4). Minerals associated with pyrrhotite and pentlandite include sporadic magnetite (Mighei and Sutter's Mill), phosphide around a sulfide grain in one instance (Mighei), and EDS suggests Ir-bearing and Y-bearing Nirich sulfides (Mighei; EA-2). The Ir-bearing sulfide may be similar to platinum-groupelement bearing sulfides (e.g., [Os,Ru,Ir]S ${ }_{2}$ ) observed by Geiger and Bischoff (1995) in the CK chondrites. In addition, Sutter's Mill also contains what appears to be a hydroxysulfide. Fe,Ni metal was observed in association with pyrrhotite and pentlandite in a single instance in Mighei. Mineral phases surrounding sulfides include olivine, pyroxene, plagioclase, and phyllosilicates.

\subsubsection{CK chondrites}

Pentlandite (17.3-41.8 wt.\% Ni) is the most common sulfide in the CK chondrites and is associated with pyrrhotite and pyrite (Figs. 1b and 3, EA-1, and Table 4). Pentlandite is present as lamellae within pyrrhotite/pyrite and as blocky grains with islands of pyrrhotite/pyrite (Fig. 1b). Magnetite and ilmenite are ubiquitous accessory minerals, while chalcopyrite and Co-rich pentlandite are minor (in ALH 85002 and Karoonda; Figs. 2a, 3, EA-2, and Table 2), and a Y,Ru sulfide (in ALH 85002) and Agbearing sulfide (in Karoonda; EDS analyses suggest it is $\mathrm{Ag}_{2} \mathrm{~S}$ ) are rare (EA-2). Rare Rubearing sulfides and Ag-bearing sulfides were also observed in the CK chondrites by Geiger and Bischoff (1995). Fe,Ni metal was not observed in association with sulfides. Pyrrhotite and pyrite are typically Ni-rich, containing 0.08-15.7 wt.\% Ni (avg. 3.0 \pm 4.5 wt.\% [1б]; Table 4). One analysis of Cu-rich pentlandite in ALH 85002 is not included in Table 4, but contains 28.4 wt.\% Ni, 0.05 wt.\% Cr, 9.7 wt.\% Cu, and $\mathrm{Co}$ is below detection limit (bdl). Mineral phases surrounding sulfides include olivine, pyroxene, and plagioclase. 
Pyroxene is compositionally homogeneous in LEW 87009 (CK6; $\mathrm{Fs}_{25.6 \pm 0.5} \mathrm{En}_{73.8 \pm 0.6} \mathrm{Wo}_{0.7 \pm 0.1}, \mathrm{~N}=7 ; ; \mathrm{Fs}_{11.3 \pm 0.9} \mathrm{En}_{41.3 \pm 0.6} \mathrm{Wo}_{47.4 \pm 0.8}, \mathrm{~N}=8$ ). In LAP 06868 (CK5) LCP is homogenous $\left(\mathrm{Fs}_{24.8 \pm 0.4} \mathrm{En}_{74.4 \pm 0.4} \mathrm{Wo}_{0.8 \pm 0.2}, \mathrm{~N}=14\right)$, however $\mathrm{HCP}$ is compositionally heterogeneous $\left(\mathrm{Fs}_{11.3 \pm 3.8} \mathrm{En}_{42.2 \pm 5.8} \mathrm{Wo}_{46.5 \pm 2.4}, \mathrm{~N}=11\right)$.

\subsubsection{LL chondrites}

While uncommon, pentlandite (16.0-23.7 wt.\% Ni) was observed in all four LL chondrites studied, is present as all three textural types, and is associated with pyrrhotite (Figs. 1c, 2b, and 3, EA-1, and Table 4). However, pentlandite is only present as lamellae within pyrrhotite (bdl-15.3 wt.\% Ni) in Semarkona. Pentlandite in Semarkona has a lower average Ni content than that in the LL4-6 chondrites (Table 4). Fe,Ni-metal (kamacite and taenite) and chromite are common accessory minerals, while molybdenite (associated with pyrrhotite and found only in Soko-Banja; Fig. 2b and EA-2), ilmenite (Siena), and Cu-rich sulfide ( 1.7 wt.\% Cu in Siena and $\sim 15$ wt.\% Cu in Saint-Séverin) are rare. Fe,Ni metal was occasionally observed in association with sulfides. Mineral phases surrounding sulfides include olivine, pyroxene, and plagioclase; phyllosilicates were not observed. The vast majority of sulfides studied in Semarkona are in chondrules with clear glassy mesostasis. Magnetite, potentially an aqueous alteration product, was observed in the matrix of Semarkona.

Pyroxene is compositionally homogeneous in Siena (LL5; Fs $23.7 \pm 0.5 \mathrm{En}_{74.9 \pm 0.5} \mathrm{Wo}_{1.4 \pm 0.3}$, $\left.\mathrm{N}=13 ; \quad \mathrm{Fs}_{8.8 \pm 0.4} \mathrm{En}_{46.8 \pm 0.3} \mathrm{Wo}_{44.4 \pm 0.5}, \quad \mathrm{~N}=14\right) \quad$ and $\quad$ Saint-Séverin (LL6; $\left.\mathrm{Fs}_{23.3 \pm 0.3} \mathrm{En}_{75.1 \pm 0.3} \mathrm{Wo}_{1.6 \pm 0.1}, \mathrm{~N}=11 ; \mathrm{Fs}_{9.3 \pm 0.5} \mathrm{En}_{47.1 \pm 0.4} \mathrm{Wo}_{43.5 \pm 0.6}, \mathrm{~N}=13\right)$.

\subsection{4. $R$ chondrites}

Pentlandite (19.1-38.6 wt.\% Ni) is common in the $\mathrm{R}$ chondrites, it is present as blocky grains, blebs, and lamellae in association with pyrrhotite (bdl-15.3 wt.\% Ni) (e.g., Figs. 1d,e, and 3, EA-1, and Table 4). Chromite is a common accessory mineral, while chalcopyrite is uncommon (present in MET 01149, LAP 031275, and LAP 03639; e.g., Figs. 1d,e, and 2c), and magnetite is rare (MET 01149; EA-1). In some cases, the sulfides are polycrystalline (multiple crystals are discernable due to different orientations of pentlandite lamellae; MET 01149, MIL 11207, and LAP 04840; Fig. 1d). Fe,Ni metal 
was not observed in association with pyrrhotite and pentlandite. Mineral phases surrounding sulfides include olivine, pyroxene, and plagioclase. Amphibole was observed in both LAP 04840 and MIL 11207.

While LAP 03639 is officially classified as an R4 and LAP 031275 as an R5 (Satterwhite and Righter, 2008), based on the unequilibrated nature of LAP 031275 (presence of FeO-poor chondrules) and relatively equilibrated nature of LAP 03639, we suggest that LAP 03639 is an R5 and LAP 031275 is an R4 (Table 1).

Pyroxene is compositionally homogeneous in MET 01149 (R3; $\mathrm{Fs}_{28.4 \pm 1.4} \mathrm{En}_{70.6 \pm 1.5} \mathrm{Wo}_{1.1 \pm 0.2}, \quad \mathrm{~N}=9 ; \quad \mathrm{Fs}_{9.7 \pm 0.7} \mathrm{En}_{45.5 \pm 0.7} \mathrm{Wo}_{44.8 \pm 1.0}, \quad \mathrm{~N}=9$ ), LAP 031275 (R4; $\mathrm{Fs}_{29.2 \pm 0.7} \mathrm{En}_{69.5 \pm 1.0} \mathrm{Wo}_{1.3 \pm 0.4}, \mathrm{~N}=9 ; \mathrm{Fs}_{10.9 \pm 1.0} \mathrm{En}_{44.9 \pm 0.7} \mathrm{Wo}_{44.3 \pm 1.4}, \mathrm{~N}=7$ ), and LAP 03639 (R5; $\left.\mathrm{Fs}_{25.7 \pm 2.5} \mathrm{En}_{75.2 \pm 3.2} \mathrm{Wo}_{2.1 \pm 1.0}, \mathrm{~N}=9 ; \mathrm{Fs}_{9.7 \pm 1.1} \mathrm{En}_{45.6 \pm 1.1} \mathrm{Wo}_{44.7 \pm 2.1}, \mathrm{~N}=6\right)$.

\subsubsection{Brachinite}

Sulfides within EET 99402 are rare and typically pyrrhotite (bdl-11.6 wt.\% Ni), with rare pentlandite (18.9-19.6 wt.\% Ni; Fig. 3, and EA-1, and Table 4). Pentlandite is present as blebs and lamellae morphological types (e.g., Fig. 1f), and is associated with pyrrhotite. Rare Fe,Ni-metal and more abundant chromite are often associated with sulfides. However, Fe,Ni-metal and pentlandite are not observed associated together. Mineral phases observed in contact with sulfides include olivine, pyroxene, and plagioclase.

\subsection{Closure temperatures and oxidation states}

Two-pyroxene closure temperatures were determined for equilibrated samples with homogeneous LCP and HCP compositions. These temperatures vary between meteorite groups and agree with literature values (Tables 1 and 3). Although two-pyroxene literature values exist for Saint-Séverin, closure temperatures for Siena (LL5) and SaintSéverin (LL6) were determined to verify the technique used here. The weighted mean temperatures, with two standard error of the mean (2SE) uncertainties, are $867 \pm 28^{\circ} \mathrm{C}(10$ pairs) for Siena and $899 \pm 70^{\circ} \mathrm{C}$ (5 pairs) for Saint-Séverin; nearly identical to the SaintSéverin value of Slater-Reynolds and McSween (2005) $\left(897 \pm 104^{\circ} \mathrm{C}\right.$; Table 1). Mineral 
pairs from a chondrule in Siena and those in the matrix give the same temperatures within uncertainties, indicating thermal equilibration. Utilizing the QIFs buffer reaction at twopyroxene temperatures, Eq. (1) and (2), the $f \mathrm{O}_{2} \mathrm{~s}$ for Siena and Saint-Séverin are determined to be IW-2.2 and IW-1.9, respectively.

The weighted mean two-pyroxene temperature determined for the CK6 LEW 87009 is $740 \pm 38^{\circ} \mathrm{C}$ (5 pairs; Table 1). A temperature for LAR 06868 (CK5) was not determined because it contains compositionally heterogeneous HCP. However, LAR 06868 has recognizable relict chondrules unlike LEW 87009, suggesting either the peak temperature for LAR 06868 was lower or the duration of heating was shorter than that of LEW 87009. This temperature is similar to peak metamorphic temperatures estimated by Chaumard and Devouard (2016) using $\mathrm{Fe} / \mathrm{Mg}$ interdiffusion: $\mathrm{CK} 3$ chondrites between $577^{\circ} \mathrm{C}$ and $647^{\circ} \mathrm{C}$, and CK4-6 chondrites between $647^{\circ} \mathrm{C}$ and $867^{\circ} \mathrm{C}$ (Table 1).

The weighted mean temperature determined for LAP 03639 (R5) is $853 \pm 62^{\circ} \mathrm{C}$ (5 pairs) (Tables 1 and 3). Closure temperatures, within uncertainty, were the same between mineral pairs within chondrules, the matrix, and the R6 clast in LAP 03639. Although LCP and HCP are compositionally homogeneous in MET 01149 and LAP 031275, closure temperatures were not determined because both samples contain unequilibrated olivine. Closure temperatures were not determined for either R6 chondrite studied, LAP 04840 and MIL 11207, as HCP was not observed; it was probably replaced by amphiboles during aqueous alteration (McCanta et al., 2008; Gross et al., 2013; Rubin, 2014). However, FeNiS veins observed in MIL 11207 constrain the minimum metamorphic temperature of this sample to $\geq 950^{\circ} \mathrm{C}$ (the $\mathrm{Fe}, \mathrm{Ni}-\mathrm{FeS}$ eutectic; Kullerud, 1963b; McCoy et al., 2006), consistent with its lack of recognizable relict chondrules.

\section{DISCUSSION}

\subsection{Relationship of sulfide mineralogy with oxygen fugacity}

While the presence of pentlandite alone does not indicate a particular formation mechanism, it does constrain a minimum $f_{2}$ (in the presence of sufficient $\mathrm{S}$ ). Comparison of pentlandite presence with the calculated $f \mathrm{O}_{2}$ for each bulk sample for 
equilibrated samples or host chondrule for unequilibrated samples shows that it is controlled primarily by the $\mathrm{fO}_{2}$ of formation. In addition to the observations of meteoritic sulfides in this study, experimental petrologists have shown that the composition of Fe-S$\mathrm{O}$ liquids at any temperature is a function of its $f \mathrm{O}_{2}$ and $f \mathrm{~S}_{2}$ (Naldrett, 1969; 2004; Kress, 1997). In settings with sulfide droplets surrounded by silicates, as in the meteorites discussed here, Naldrett (1969) suggested that the sulfide droplets may have lost their O to the surrounding silicates at subsolidus temperatures. While we argue that the composition of the Fe-Ni-S liquid was determined by the surrounding $f \mathrm{O}_{2}$ and $f \mathrm{~S}_{2}>950^{\circ} \mathrm{C}$ we cannot rule out local disequilibrium effects during cooling discussed by Jamsja and Ruzicka (2010).

While troilite (Ni-free, stoichiometric FeS) is known to form under reducing (i.e., low $f \mathrm{O}_{2}$ ) conditions (e.g., Evans, 1970), pentlandite formation requires an oxidizing (i.e., high $f \mathrm{O}_{2}$ ) environment because the incorporation of $\mathrm{Fe}$ into oxidized minerals (silicates/oxides/phyllosilicates) lowers its availability for sulfide formation. The scarcity of Fe,Ni-metal results in sulfides that are enriched in Ni. Furthermore, Schrader et al. (2015a) found that in high temperature $\left(600-400^{\circ} \mathrm{C}\right)$ sulfides, only sulfide assemblages with bulk Ni contents >3 wt.\% ( 2.4 at.\% Ni) contained pentlandite, indicating the minimum bulk Ni content for exsolution to occur.

Pentlandite was observed in all meteorites studied here, and always in association with FeO-rich minerals. Pentlandite was found distributed across FeO-rich samples, such as the brachinite EET 99402 (avg. $\mathrm{Fa}_{35.8 \pm 0.2}$; Gardner-Vandy et al., 2013), and within FeO-rich chondrules $(\mathrm{Fa}>10)$ of relatively less oxidized samples. Pentlandite was also found in the matrices and chondrules of the CK chondrites (highly-oxidized) and the CM chondrites (aqueously altered). Samples that formed under oxidizing conditions have less Fe,Ni-metal and, consequently, more pentlandite.

\subsubsection{Bulk $\mathrm{fO}_{2}$ and pentlandite in equilibrated chondrites}

The CK $\left(\mathrm{Fa}_{29-33}\right)$ and $\mathrm{R}\left(\mathrm{Fa}_{38-40}\right)$ chondrites are highly oxidized (more so than the LL chondrites) with $f \mathrm{O}_{2}$ relative to the iron-wüstite (IW) buffer of IW+7.5 and IW to IW+3, respectively (Kallemeyn et al., 1991; Weisberg et al., 2006; Righter and Neff, 2007; Satterwhite and Righter, 2008). They also contain the most abundant pentlandite. As they 
formed at higher $f \mathrm{O}_{2}$, the $\mathrm{CK}$ and $\mathrm{R}$ chondrites typically contain trace amounts of $\mathrm{Fe}, \mathrm{Ni}$ metal (Geiger and Bischoff, 1995; Weisberg et al., 2006) and have abundant pentlandite that is far more Ni-rich compared to that of LL chondrites (Fig. 3 and Table 4).

Equilibrated LL chondrites are the most oxidized OCs $\left(\mathrm{Fa}_{27-32}\right.$; Weisberg et al., 2006; IW-2.2 to -1.9), yet still contain $\sim 2$ vol.\% Fe,Ni-metal (much of which is Ni-rich) which limits the amount of $\mathrm{Ni}$ for incorporation into sulfides; consistent with pentlandite being uncommon and low in $\mathrm{Ni}$ content.

While less abundant, pentlandite is also present in the brachinite ( IW-1.0 for brachinites; Gardner-Vandy et al., 2013).

\subsubsection{Site-specific $\mathrm{fO}_{2}$ and pentlandite in unequilibrated chondrites}

The location of pentlandite in unequilibrated chondrites is typically restricted to $\mathrm{FeO}$ rich chondrules, rare FeO-poor chondrules, and occasionally in the matrix. The following $\mathrm{fO}_{2}$ values from the literature were determined for individual chondrules. Pentlandite is common in FeO-rich chondrules from the LL (IW-1.7 to -0.4; Zanda et al., 1994), CM, and CR (IW-1.6 to -0.6; Schrader et al., 2013) chondrites. However, pentlandite is nearly always absent from the more reduced FeO-poor chondrules from the CR (IW-4.0 to -2.3; Zanda et al., 1994; Schrader et al., 2013), CM (IW-4.0 to -3.4; Zanda et al., 1994), and LL chondrites (IW-4.2 to -2.5 ; Zanda et al., 1994). The most oxidized FeO-poor chondrules that are pentlandite-free (IW-2.3, Schrader et al., 2013) formed at nearly the same $f \mathrm{O}_{2}$ under which LL chondrites were thermally metamorphosed (IW-2.2, this study), suggesting they formed in a S-poor gas and that the sulfur fugacity of a system is also a contributing factor for pentlandite formation. The only sulfides in IAB iron meteorite silicate clasts (IW-3.2 to $-2.9, f_{2}$ at olivine-spinel temperatures) are Ni-poor pyrrhotite (Benedix et al., 2005). Therefore, while $\mathrm{fO}_{2}$ is not the only factor, samples (whole-rocks or chondrules) that formed under conditions more reducing than $\sim$ IW-2.2 do not contain pentlandite. However, systems that were more oxidizing and had sufficient $\mathrm{S}$ contain more pentlandite. If pentlandite in aqueously altered chondrites was all formed via aqueous alteration, it would be present in both FeO-poor and FeO-rich chondrules. Therefore, this trend supports an $f_{2}$ dependency for high-temperature pentlandite formation, instead of being solely a secondary aqueous alteration product. 


\subsection{Petrology, composition, and equilibration temperatures}

The compositions of pyrrhotite and pentlandite vary with closure temperature. Through experimental petrology equilibrium phase diagrams at a range of temperatures in the Fe-Ni-S system have been developed (e.g., Kullerud, 1963a; Kullerud et al., 1969; Misra and Fleet, 1973; Francis et al., 1976; Naldrett, 1989; 2004; Karup-Moeller and Makovicky, 1995; Sugaki and Kitakaze, 1998; Etschmann et al., 2004; Raghavan, 2004a). The composition of pyrrhotite and pentlandite, in comparison to these diagrams, can be used to constrain their closure/equilibration temperature. To estimate the sulfide equilibration temperature for samples studied here, the compositions of sulfides from each meteorite are shown on Fe-Ni-S phase diagrams at 100 to $135^{\circ} \mathrm{C}, 230^{\circ} \mathrm{C}, 400^{\circ} \mathrm{C}$, $500^{\circ} \mathrm{C}, 600^{\circ} \mathrm{C}$, and $725^{\circ} \mathrm{C}$ in EA-3. With increasing equilibration temperature, pentlandite becomes richer in both $\mathrm{S}$ and $\mathrm{Ni}$ (EA-3). Representative phase diagrams that match the compositions of some sulfides in each group are shown in Figure 5. While the vast majority of analyzes were conducted on phase pure grains larger than the interaction volume of the EPMA, there were undoubtedly some beam overlaps between Ni-poor and Ni-rich sulfides. However, any overlaps would likely plot along mixing-lines on an Fe$\mathrm{Ni}-\mathrm{S}$ phase diagram, and would therefore plot along or near tie-lines.

The morphologies and compositions of sulfides vary between meteorite groups (Figs. 1 and 2, and EA-1), and between petrographic subtypes within groups. The textures and equilibration temperatures of sulfides, combined with the sample's thermal history, constrain their formation mechanism(s). None of the sulfides studied here have Fe-Ni-S compositions consistent with equilibrating above $600^{\circ} \mathrm{C}$ (EA-3), indicating that pentlandite studied here is not the high-temperature form of pentlandite that is stable up to $865^{\circ} \mathrm{C}$ (Sugaki and Kitakaze, 1998). This is in contrast to Chaumard and Devouard (2016), where the high-temperature form of pentlandite was considered to be present in CK chondrites based on estimated peak metamorphic temperatures.

The relationship of minor elements (e.g., $\mathrm{Co}, \mathrm{P}, \mathrm{Cu}$, and $\mathrm{Cr}$ ) with the $\mathrm{Ni}$ content of meteoritic sulfides is consistent with their behavior in terrestrial magmatic sulfide ore deposits (Dare et al. 2010; e.g., Fig. 3 and Tables 2 and 4). In sulfides from the Sudbury 
igneous complex (an impact melt sheet) Co partitions into pentlandite and is depleted in pyrrhotite (Dare et al., 2010), consistent with melt partitioning experiments (Raghavan, 1998; 2004b; Soltanieh et al. 1999). This behavior is also consistent with sulfides studied here (Fig. 3), with the exception of some sulfides in the CK chondrites. The increase of Co with Ni abundance becomes clear at $~ 16$ wt.\% Ni (Fig. 3), indicating that this marks the compositional separation between pyrrhotite and pentlandite. Sulfides in samples of higher petrographic type typically have higher Co contents (Fig. 3). Pentlandite typically contains more Co than Ni-poor sulfides such as pyrrhotite; while the oxidized CK chondrites and the brachinite contain abundant Co in both Ni-poor and Ni-rich sulfides. Co may be incorporated into pyrrhotite and pentlandite in the most oxidized samples because at high $f \mathrm{O}_{2}$ there is little to no $\mathrm{Fe}$,Ni-metal and neither magnetite nor chromite contains Co (e.g., Davidson et al., 2014b), making Co available for incorporation into sulfides.

\subsubsection{CM chondrites}

The CM chondrites experienced extensive 'low-temperature' aqueous alteration $\left(<220^{\circ} \mathrm{C}\right.$ for Mighei [Busemann et al., 2007]; 150 to $500^{\circ} \mathrm{C}$ for Sutter's Mill lithologies [Jenniskens et al., 2012]; Fig. 4 and Table 1). Aqueously altered minerals (i.e., phyllosilicates) were commonly, but not always, observed near sulfides. Although the composition of pyrrhrotite and pentlandite are broadly consistent with a range of equilibration temperatures (EA-3), the composition of pyrrhotite is most consistent with equilibrating between 100 and $135^{\circ} \mathrm{C}$ (Fig. 5a). However, some pentlandite in Sutter's Mill is relatively depleted in $\mathrm{S}$ and therefore we cannot rule out equilibration at temperatures up to $600^{\circ} \mathrm{C}$ (Fig. $5 \mathrm{~b}$ and EA-3). This contradicts the common inference that pentlandite is solely an aqueous product in the CM chondrites (e.g., Zolensky and Le, 2003; Brearley, 2006). Furthermore, pentlandite abundance is independent of the degree of whole-rock aqueous alteration in the CM chondrites (Zolensky and Le, 2003), which we interpret as evidence that it did not form solely via aqueous alteration. Lamellar and oriented bleb morphologies of pentlandite are inconsistent with formation via aqueous alteration (Fig. 1a and EA-1), and their equilibration temperatures indicate formation during cooling from high temperature; perhaps during chondrule cooling. However, most 
$\mathrm{CM}$ chondrite sulfides are consistent with equilibration temperatures of 100 to $135^{\circ} \mathrm{C}$, and likely formed via aqueous alteration (Zolensky and Le, 2003; Brearley, 2006), and/or by low-temperature annealing or metamorphism (e.g., Brearley and Martinez, 2010; Kimura et al., 2011). Therefore, sulfides in the CM chondrites record a complex set of formation conditions.

\subsubsection{CK chondrites}

Pentlandite is the dominant sulfide in the CK chondrites, and is present as lamellae within pyrrhotite/pyrite and blocky grains containing islands of pyrrhotite/pyrite (Fig. 1b). Sulfides were not associated with aqueously altered minerals. The composition of pentlandite is broadly consistent with a range of equilibration temperatures (EA-3), however the composition of pyrite and pyrrhotite indicate that sulfides in the CK4 chondrites equilibrated at $230^{\circ} \mathrm{C}$ (Fig. $5 \mathrm{c}$ and EA-3). The compositions of pyrrhotite and pentlandite in the CK5-6 chondrites have S contents inconsistent with equilibration at $230^{\circ} \mathrm{C}$. However, the presence of pyrite and the compositions of pyrrhotite and pentlandite are consistent with an equilibration temperature of $500^{\circ} \mathrm{C}$ (e.g., EA-3). CK chondrite sulfides are considered to have formed during cooling from peak thermal metamorphic temperatures of 550 to $950^{\circ} \mathrm{C}$, mostly during annealing $<300^{\circ} \mathrm{C}$ (Geiger and Bischoff, 1995). Recently Chaumard and Devouard (2016) estimated metamorphic temperatures of between $647^{\circ} \mathrm{C}$ and $867^{\circ} \mathrm{C}$ for the CK4-6 chondrites (Fig. 4 and Table 1). These previously determined metamorphic temperatures are consistent with that calculated here $\left(740 \pm 38^{\circ} \mathrm{C}\right.$ for the CK6; Table 1$)$. The nearly equal abundance of pyrite and pyrrhotite (Fig. 5c) in the CK chondrites also indicates a history of annealing; Fe-Ni$\mathrm{S}$ annealing experiments of crystallized mss show that pyrite-pentlandite assemblages form $\sim 212 \pm 13^{\circ} \mathrm{C}$ (Craig, 1973), consistent with sulfide equilibration temperatures. These experiments also resulted in Ni-rich pyrrhotite and pyrite (Craig, 1973). Pyrite exsolution is a slow process (Kissin and Scott, 1982), suggesting formation of CK sulfides by prolonged annealing. Furthermore, high-temperature (i.e., $>200^{\circ} \mathrm{C}$ ) formation of pentlandite-pyrite is consistent with the presence of chalcopyrite and Co-rich pentlandite (Figs. 2a and 3a), both of which are present in terrestrial magmatic sulfide ore deposits 
(e.g., Naldrett et al., 1967; Keays et al., 1981; Merkle and Gruenewaldt, 1986; Dare et al., 2010). In pyrite-pentlandite annealing experiments between 400 and $200^{\circ} \mathrm{C}$, chalcopyrite exsolved when 2 wt.\% $\mathrm{Cu}$ was added to experimental Fe-Ni-S charges (Craig, 1973). Furthermore, laboratory experiments determined that Fe,Co-mss decomposes into Fe-rich and Co-rich pentlandite below $425^{\circ} \mathrm{C}$ (Farrell and Fleet, 2002). Due to the compositions of pyrrhotite and pentlandite, and the presence of pyrite among pyrrhotite-pentlandite intergrowths, we find that CK4 chondrite sulfides most likely equilibrated around $230^{\circ} \mathrm{C}$ while the CK5-6 chondrites equilibrated around $500^{\circ} \mathrm{C}$ (Fig. 5c and EA-3).

Magnetite within the CK chondrites is considered to have formed by oxidation during mild aqueous alteration (e.g., Huber et al., 2006; Davidson et al., 2014b). The presence of magnetite with sulfides may indicate that pentlandite was replaced by magnetite under highly oxidizing conditions during metamorphism (Geiger and Bischoff, 1995). However, magnetite is known to crystallize co-genetically with sulfides in terrestrial magmas in the Fe-Ni-S-O system (Naldrett, 1989), and CK chondrites contain rounded magnetite blebs surrounded by pyrrhotite and pentlandite (Fig. 1b) indicating that these magnetite blebs crystallized co-genetically with sulfides. In terrestrial magmas that formed around $\mathrm{fO}_{2} \sim$ $10^{-8}\left(\mathrm{IW}+14.3\right.$ at $\sim 677^{\circ} \mathrm{C}$ ) magnetite crystallized before pyrrhotite (Doyle and Naldrett, 1986; Naldrett, 1989). Although these terrestrial magmas were thermally metamorphosed at more oxidizing conditions than $\mathrm{CK}$ chondrites, which were metamorphosed around $\mathrm{fO}_{2}$ $\sim 10^{-14.7}\left(\sim 677^{\circ} \mathrm{C}\right.$ at $\mathrm{IW}+7.5\left[f \mathrm{O}_{2}\right.$ determined from magnetite-ilmentite pairs at $950 \mathrm{~K}$ by Righter and Neff, 2007; Gardner-Vandy et al., 2013]), the CK chondrites formed at highly oxidizing conditions. Therefore, based on petrographic observations and $\mathrm{fO}_{2}$ of formation, we conclude that magnetite-sulfide intergrowths are likely magmatic and formed co-genetically, but magnetite crystallized after pyrrhotite and pentlandite from immiscible melts. This statement only applies to magnetite-sulfide intergrowths, we do not rule out the possibility that some magnetite in the CK chondrites formed by oxidation during aqueous alteration (e.g., Huber et al., 2006; Davidson et al., 2014b).

\subsubsection{LL chondrites}

Pentlandite was observed in all LL chondrites studied here and is present as all three textural types (Fig. 1c and EA-1), but lamellae are only present in Semarkona. Aqueous 
alteration products (i.e., phyllosilicates and carbonates) were not observed in association with sulfides, but magnetite was observed in the matrix of Semarkona. The compositions of pyrrhotite and pentlandinte within chondrules and matrix in Semarkona are generally consistent with equilibration temperatures between 600 and $230^{\circ} \mathrm{C}$, but pentlandite is too $\mathrm{Ni}$-poor to indicate equilibration between 100 and $135^{\circ} \mathrm{C}$ (Fig. 5d and EA-3). The compositions of the sulfides are most consistent with equilibrating at $\sim 230^{\circ} \mathrm{C}$, however we cannot rule out equilibration at temperatures up to $600^{\circ} \mathrm{C}$ because data lies along tie lines on phase diagrams up to $600^{\circ} \mathrm{C}$ (EA-3). In the LL4-6 chondrites, pyrrhotite and pentlandite are richer in $\mathrm{Ni}$ and $\mathrm{S}$ than in Semarkona, indicating equilibration at higher temperatures. The compositions of pentlandite in the LL4-6 chondrites measured here are too $\mathrm{S}$ rich to have equilibrated at or below $230^{\circ} \mathrm{C}$, and are most consistent with equilibrating between 600 and $500^{\circ} \mathrm{C}$ (Fig. 5d and EA-3). These temperatures are higher than the peak metamorphic temperature inferred for Semarkona $\left(<220^{\circ} \mathrm{C}\right.$; Busemann et al., 2007), but agree with pentlandite formation during cooling after thermal metamorphism for the LL4-6 chondrites $\left(\sim 600-900^{\circ} \mathrm{C}\right.$; McCoy et al., 1991; SlaterReynolds and McSween, 2005; this study; Fig. 4 and Table 1). This contradicts the suggestion that pentlandite within Semarkona is solely an aqueous product (Rubin, 2006). This suggests two possible formation mechanisms: (1) pentlandite within Semarkona is primary (i.e., formed during cooling after high temperature events, such as during chondrule cooling [e.g., as in the CR chondrites; Schrader et al., 2010b; 2015a]), or less likely (2) Semarkona experienced brief high-temperature $\left(600-230^{\circ} \mathrm{C}\right)$ sulfide equilibration that did not affect other diffusion-driven geothermometers (e.g., graphite ordering; olivine-chromite equilibration). Due to sulfide equilibration temperatures and the presence of pentlandite lamellae within pyrrhotite in Semarkona, we suggest that pentlandite observed within Semarkona is primary; however we cannot rule out some low-temperature annealing. Since the presence of phyllosilicates, smectite, and magnetite in the matrix of Semarkona shows that it has experienced low-temperature aqueous alteration (Hutchison et al., 1987; Alexander et al., 1989), we also cannot rule out that some sulfides formed via aqueous alteration in Semarkona (e.g., Rubin, 2006).

High-temperature formation of pentlandite in equilibrated LL chondrites is consistent with the presence of molybdenite in Soko-Banja (LL4; Fig. 2b), which is present in high- 
temperature terrestrial hydrothermal veins (e.g., Anthony et al., 1990) and primary molybdenite (i.e., not formed via aqueous alteration) has also been reported in $\mathrm{CV}$ calcium-aluminum rich inclusions (El Goresy et al., 1978). While we do not find that pyrrhotite-pentlandite intergrowths in the LL4-6 chondrites have an aqueous origin, phosphate minerals in equilibrated LL chondrites indicate the presence of fluids during metamorphism (Jones et al., 2014). Therefore, we suggest that sulfides in Semarkona are

primary and formed during chondrule cooling prior to accretion while those in LL4-6 chondrites formed at high-temperature after thermal metamorphism. Due to the duration of heating experienced by the LL chondrites (10-100 Myr; McCoy et al., 1991), lowtemperature annealing may also have played a role in sulfide equilibration.

\subsection{4. $R$ chondrites}

Pentlandite is common in the $\mathrm{R}$ chondrites and is present as blocky grains, lamellae, and oriented blebs within Ni-poor pyrrhotite (Fig. 1d,e; McCanta et al., 2008). The compositions of pyrrhotite and pentlandite in the $\mathrm{R}$ chondrites are too $\mathrm{S}$ rich to have equilibrated between 100 and $230^{\circ} \mathrm{C}$ (EA-3). The $\mathrm{S}$ content of pyrrhotite and pentlandite in the $\mathrm{R}$ chondrites are consistent with equilibration temperatures between 600 and $500^{\circ} \mathrm{C}$ (Fig. 5e and EA-3). Metamorphic temperatures for R chondrites were previously only constrained for the R6 chondrites LAP $04840\left(\sim 670^{\circ} \mathrm{C}\right.$; McCanta et al., 2008) and MIL 11207 ( $700-900^{\circ} \mathrm{C}$; Rubin, 2014). However, two-pyroxene closure temperatures indicate that the R5 chondrite LAP 03639 was heated to $853 \pm 62^{\circ} \mathrm{C}$ (Table 1). Fe-Ni-S veining observed in MIL 11207 indicates sulfide melt migration, suggesting a minimum metamorphic temperature of $\sim 950^{\circ} \mathrm{C}$ (Fe,Ni-FeS eutectic; Kullerud, 1963b; McCoy et al., 2006). Therefore, sulfide closure temperatures are lower than the metamorphic temperatures for the R chondrites (Fig. 4 and Table 1), consistent with sulfide formation during retrograde metamorphism. The consistent presence of chromite with sulfides (Figs. 1d,e and EA-3) indicates the sulfides formed under oxidizing conditions. The presence of chalcopyrite in LAP 031275 and LAP 03639 (e.g., Fig. 2c) is consistent with hightemperature formation, as it is also observed in terrestrial magmatic sulfide ores in association with pentlandite and pyrrhotite; exsolution of these phases occurred during cooling $<650^{\circ} \mathrm{C}$ (e.g., Keays et al., 1981; Dare et al., 2010). 
Chalcopyrite in $\mathrm{R}$ chondrites is suggested to form via aqueous alteration or exsolution upon cooling from high temperature (Miller et al., 2014). While LAP 04840 (McCanta et al., 2008) and MIL 11207 (Gross et al., 2013; Rubin, 2014) are aqueously altered, no chalcopyrite was observed in either sample in this study. In the R3-5 chondrites studied here, chalcopyrite is surrounded by pentlandite and pyrrhotite (Fig. 2c) with closure temperatures between 600 and $500^{\circ} \mathrm{C}$ (e.g., Fig. 5e and EA-3), suggesting a hightemperature origin for this chalcopyrite. The presence of magnetite in MET 01149 (EA1) may indicate low-temperature aqueous alteration of sulfides, co-genetic crystallization, or decomposition of pentlandite into magnetite during metamorphism under highly oxidizing conditions; similar to the CK chondrites (Geiger and Bischoff, 1995; Section 4.2.2).

\subsubsection{Brachinite}

Sulfides are uncommon, and pentlandite is rare, in the brachinite EET 99402 and is present as lamellae and blebs within Ni-poor pyrrhotite (Fig. 1f). The compositions of sulfides in this brachinite are too $\mathrm{S}$ rich to have equilibrated below $400^{\circ} \mathrm{C}$, and are most consistent with equilibration temperatures of 600 to $400^{\circ} \mathrm{C}$ (e.g., Fig. $5 f$ and EA-3). This is consistent with sulfide formation during cooling after partial melting for brachinites at temperatures in excess of $980^{\circ} \mathrm{C}$ (Gardner-Vandy et al., 2013; Fig. 4 and Table 1). Brachinites show similarities to laboratory heated $\mathrm{R}$ chondrites, suggesting the brachinite precursor material was similar to the $\mathrm{R}$ chondrites (Gardner-Vandy et al., 2013). This sample provides a potential thermal metamorphic extreme to compare to the less heated $\mathrm{R}$ chondrites, and the rarity of sulfides compared to $\mathrm{R}$ chondrites suggest brachinites lost sulfides. Whole rock $\mathrm{O}$-isotope compositions suggest distinct parent bodies for both the $\mathrm{R}$ chondrites and the brachinites; the brachinite parent body experienced a higher degree of thermal metamorphism (e.g., Gardner-Vandy et al., 2013). However, similar sulfide equilibration temperatures suggest they are representative of closure temperatures during retrograde metamorphism.

\subsection{Duration of thermal metamorphism}


The composition and morphology of pyrrhotite-pentlandite intergrowths are also indicative of formation timescales. Pyrrhotite-pentlandite textures similar to those observed in meteoritic samples studied here have been produced via annealing experiments of $\mathrm{Fe}-\mathrm{Ni}-\mathrm{S}$ charges between $\sim 500$ and $200^{\circ} \mathrm{C}$ by exsolution of pentlandite and pyrrhotite from mss (e.g., Craig, 1973; Misra and Fleet, 1973; Etschmann et al., 2004). However, experimental pyrrhotite is Ni-rich while pyrrhotite in meteorites is typically Ni-poor. Some Ni-rich pyrrhotite analyses in this study likely result from overlap of micron-scale intergrowths of Ni-poor pyrrhotite and pentlandite blebs. Although pentlandite-pyrrhotite exsolution experiments were conducted on laboratory timescales of $24 \mathrm{hrs}$, extrapolation to geological timescales suggest that exsolution in nature may be on the order of 3,000 to 30,000 years (for sulfides rich in S; Etschmann et al., 2004). Some meteorite parent bodies were heated in excess of this exsolution timescale; for example, the CK chondrites were metamorphosed between 70,000 years (Chaumard and Devouard, 2016) and 11 Ma (Davidson et al., 2014b), while the equilibrated LL chondrites were heated on the order of 10-100 Ma (McCoy et al., 1991). In contrast, pentlandite completely exsolved from pyrrhotite in CR chondrite sulfides, which cooled from immiscible Fe-Ni-S melts (Schrader et al., 2015a) on the order of hours to days during chondrule cooling (e.g., Hewins et al., 2005; Schrader and Lauretta, 2010). Therefore, complete partitioning of $\mathrm{Ni}$ into pentlandite from pyrrhotite at temperatures $<500^{\circ} \mathrm{C}$ appears possible only over long timescales on the order of thousands of years, or by cooling from above Fe-Ni-S liquidus temperatures $\left(>950^{\circ} \mathrm{C}\right)$ on the order of hours to days. Sulfide formation at low-temperature is also possible on the order of hours via hydrothermal methods (Kissin and Scott, 1982), which is likely relevant for some sulfides in the $\mathrm{CM}$ chondrites.

\subsection{Implications for Sample Return}

Understanding the formation pathways of individual minerals within extraterrestrial materials is essential for constraining the formation and evolution of their parent bodies. The presence of Ni-rich sulfides, primarily pentlandite, was used to suggest that comet Wild 2 may have experienced limited aqueous alteration (Zolensky et al., 2008); 
consistent with the identification of rare carbonates and apparent lack of phyllosilicates in Wild 2 samples (e.g., Zolensky et al., 2008). Pyrrhotite grains in Stardust samples from Wild 2 were found to be structurally and compositionally consistent with equilibration temperatures of 100 to $135^{\circ} \mathrm{C}$, indicating low-temperature aqueous alteration (Berger et al., 2011). A re-examination of the data reported by Berger et al. (2011), in light of our measurements of chondritic sulfides here, suggests an alternative interpretation. The Nipoor and Ni-rich sulfide compositions from Wild 2 reported by Berger et al. (2011) contain $>50$ at. $\% \mathrm{~S}$, which is consistent with equilibration at temperatures $>230^{\circ} \mathrm{C}$ (up to $600^{\circ} \mathrm{C}$ ) and not between 100 and $135^{\circ} \mathrm{C}$ (e.g., Fig. 5 for phase diagrams). A sulfide equilibration temperature between 230 and $600^{\circ} \mathrm{C}$ indicates that low-temperature annealing or cooling from high temperature are also viable formation mechanisms. This interpretation is supported by recent work on the compositions and textures of Wild 2 sulfides, which indicate they formed at high temperatures and crystallized from Fe-Ni-S melts (Joswiak and Brownlee, 2016). This conclusion is also consistent with the observation of other high temperature phases, such as in chondrule-like objects, identified in comet Wild 2 (e.g., Ogliore et al., 2012; Nakashima et al., 2015).

Therefore, the presence of pentlandite in extraterrestrial samples (meteorites, IDPs, and returned samples from comets and asteroids) does not indicate a particular formation mechanism. If possible, the morphology and composition of pentlandite and coexisting sulfide minerals should be considered and compared to the thermal history of the host sample. If petrographic context is lost, as may be the case for returned samples, the morphology and composition of pentlandite alone can provide valuable information on pre- and post-accretionary processes (i.e., time, temperature, $f \mathrm{O}_{2}$, and aqueous history). This framework should be utilized if pentlandite is observed in returned samples from the C- and B-type asteroids, asteroid 162173 Ryugu and 101955 Bennu, to be collected by Hayabusa2 and OSIRIS-REx, respectively (Hasegawa et al., 2008; Emery et al., 2014; Tachibana et al., 2014; Lauretta et al., 2015).

\section{CONCLUSIONS}


The combined morphologic, compositional, and petrographic setting characteristics of pyrrhotite-pentlandite intergrowths can be utilized to constrain their formation mechanism(s).

1. $\mathrm{CM}$ and $\mathrm{CK}$ chondrite sulfides are complex as they equilibrated over a wide range of temperatures; between 600 and $100^{\circ} \mathrm{C}$, and 500 and $230^{\circ} \mathrm{C}$, respectively. $\mathrm{CM}$ chondrite sulfides mostly formed during low-temperature during aqueous alteration and/or annealing, although some may have formed at high-temperature during chondrule cooling. CK chondrite sulfides formed during cooling after thermal metamorphism and by 'low-temperature' annealing; $\sim 230^{\circ} \mathrm{C}$ for the $\mathrm{CK} 4$, and $\sim 500^{\circ} \mathrm{C}$ for $\mathrm{CK} 5-6$ chondrites.

2. Sulfides in the LL chondrites, $\mathrm{R}$ chondrites, and brachinite equilibrated between 600 and $230^{\circ} \mathrm{C}, 600$ and $500^{\circ} \mathrm{C}, 600$ and $400^{\circ} \mathrm{C}$, respectively. Sulfides in Semarkona (LL3.00) are consistent with formation during chondrule cooling, although we cannot rule out some low temperature annealing. Sulfides from the $\mathrm{R}$ and equilibrated LL chondrites (types 4-6) and the brachinite formed during cooling after thermal metamorphism.

3. The duration of thermal metamorphism for the CK chondrites (>11 Ma; Davidson et al., 2014b) and the equilibrated LL chondrites $\left(10^{7}-10^{8}\right.$ years; McCoy et al., 1991) were sufficient for complete separation of pentlandite and pyrrhotite.

4. The presence of pentlandite alone does not indicate a particular formation mechanism but can constrain a minimum $f \mathrm{O}_{2}$ of $\sim \mathrm{IW}-2.2$, although the formation of pentlandite is also dependent on the availability of S. The morphology and composition of pentlandite-pyrrhotite/pyrite are required to determine the formation mechanism: low-temperature annealing; aqueous alteration; and preand post-accretionary high-temperature formation. Most pyrrhotite and pentlandite in chondrites formed via high temperature processes, either upon cooling after chondrule melting prior to accretion or thermal metamorphism on the parent body.

5. The evaluation of a single mineral system, Fe-sulfides, within meteorites that retain petrographic context is vital to interpret the formation and alteration 
processes recorded by small extraterrestrial samples, such as those returned by the Stardust (comet 81P/Wild 2) and Hayabusa (asteroid 25143 Itokawa) missions and will be returned by OSIRIS-REx (asteroid 101955 Bennu) and Hayabusa2 (asteroid 162173 Ryugu). 


\section{Acknowledgements.}

For supplying the samples that were necessary for this work, the authors would like to thank: the Smithsonian Institution, the members of the Meteorite Working Group, Cecilia Satterwhite and Kevin Righter (NASA, Johnson Space Center), and Anne Black. US Antarctic meteorite samples are recovered by the Antarctic Search for Meteorites (ANSMET) program, which has been funded by NSF and NASA, and characterized and curated by the Department of Mineral Sciences of the Smithsonian Institution and Astromaterials Curation Office at NASA Johnson Space Center. We are grateful to Tim Gooding and Adam Mansur for assistance with the SEM, and Tim Rose, Emma Bullock, and Steve Lynton for assistance with the EPMA, and helpful discussions with Thomas Zega. Constructive comments by Alex Ruzicka, an anonymous reviewer, and Associate Editor Anders Meibom significantly improved the quality of the manuscript. 


\section{REFERENCES}

Alexander C. M. O'D., Barber D. J., and Hutchison R. (1989) The microstructure of Semarkona and Bishunpur. Geochim. Cosmochim. Acta 53, 3045-3057.

Anderson D. J., Lindsley D. H. and Davidson P. M. (1993) QUILF: A PASCAL program to assess equilibria among $\mathrm{Fe}-\mathrm{Mg}-\mathrm{Ti}$ oxides, pyroxenes, olivine, and quartz. Comput. Geosci. 19, 1333-1350.

Anthony J. W., Bideaux R. A, Bladh K. W. and Nichols M. C. (1990) Handbook of mineralogy. Volume 1: Elements, sulfides, sulfosalts. Mineral Data Publishing, Tucson. pp. 588.

Benedix G. K., Lauretta D. S. and McCoy T. J. (2005) Thermodynamic constraints on the formation conditions of winonaites and silicate-bearing IAB irons. Geochim. Cosmochim. Acta 69, 5123-5131.

Berger E. L., Zega T. J., Keller L. P. and Lauretta D. S. (2011) Evidence for aqueous activity on comet 81P/Wild 2 from sulfide mineral assemblages in Stardust samples and CI chondrites. Geochim. Cosmochim. Acta 75, 3501-3513.

Brearley A. J. (2006) The Action of Water. In Meteorites and the Early Solar System II (eds. D. S. Lauretta and H. Y. McSween). University of Arizona Press, Tucson. pp. 584-624.

Brearley A. J. and Martinez C. (2010) Ubiquitous exsolution of pentlandite and troilite in pyrrhotite from the TIL 91722 CM2 carbonaceous chondrite: A record of low temperature solid state processes. Lunar Planet. Sci. XLI. Lunar Planet. Inst.. Houston. \#1689 (abstr.).

Bullock E. S., Gounelle M., Lauretta D. S., Grady M. M. and Russell S. S. (2005) Mineralogy and texture of Fe-Ni sulfides in CI1 chondrites: Clues to the extent of aqueous alteration on the CI1 parent body. Geochim. Cosmochim. Acta 69, 26872700.

Busemann H., Alexander C. M. O'D. and Nittler L. R. (2007) Characterization of insoluble organic matter in primitive meteorites by microRaman spectroscopy. Meteorit. Planet. Sci. 42, 1387-1416.

Chaumard N. and Devouard B. (2016) Chondrules in CK carbonaceous chondrites and thermal history of the CV-CK parent body. Meteorit. Planet. Sci. 51, 547-573.

Clayton R. N., Onuma N., Grossman L. and Mayeda T. K. (1977) Distribution of the presolar component in Allende and other carbonaceous chondrites. Earth and Planet. Sci. Lett. 34, 209-224.

Craig J. R. (1973) Pyrite-pentlandite asssemblages and other low temperature relations in the Fe-Ni-S sytem. Am. J. Sci. 273-A, 496-510.

Craig J. R., Naldrett A. J. and Kullerud G. (1968) The Fe-Ni-S System: $400^{\circ} \mathrm{C}$ isothermal diagram. Carnegie I. Wash. 66, 440-441.

Dare S. A. S., Barnes S. -J. and Prichard H. M. (2010) The distribution of platinum group elements (PGE) and other chalcophile elements among sulfides from the Creighton $\mathrm{Ni}-\mathrm{Cu}$-PGE sulfide deposit, Sudbury, Canada, and the origin of palladium in pentlandite. Miner. Deposita 45, 765-793.

Davidson J., Schrader D. L., Alexander C. M. O’D., Lauretta D. S., Busemann H., Franchi I. A., Greenwood R. C., Connolly H. C. Jr., Domanik K. J. and Verchovsky A. (2014a) Petrography, stable isotope compositions, microRaman spectroscopy, and 
presolar components of Roberts Massif 04133: A reduced CV3 carbonaceous chondrite. Meteorit. Planet. Sci. 49, 2133-2151.

Davidson J., Krot A. N., Nagashima K., Hellebrand E. and Lauretta D. S. (2014b) Oxygen isotope and chemical compositions of magnetite and olivine in the anomalous CK3 Watson 002 and ungrouped Asuka-881595 carbonaceous chondrites: Effects of parent body metamorphism. Meteorit. Planet. Sci. 49, 1456-1474.

Doyle C. D. and Naldrett A. J. (1986) Ideal mixing of divalent cations in mafic magma and its effect on the solution of ferrous oxide. Geochim. Cosmochim. Acta 50, 435443.

El Goresy A., Nagel K. and Ramdohr P. (1978) Fremdlinge and their noble relatives. Lunar Planet. Sci. IX. Lunar Planet. Inst., Houston. 1279-1303 (abstr.).

Emery J. P., Fernández Y. R., Kelley M. S. P., Warden (nèe Crane) K. T., Hergenrother C., Lauretta D. S., Drake M. J., Campins H. and Ziffer J. (2014) Thermal infrared observations and thermophysical characterization of OSIRIS-Rex target asteroid (101955) Bennu. Icarus 234, 17-35.

Etschmann B., Pring A., Putnis A., Grguric B. A. and Studer A. (2004) A kinetic study of the exsolution of pentlandite $(\mathrm{Ni}, \mathrm{Fe})_{9} \mathrm{~S}_{8}$ from the monosulfide solid solution $(\mathrm{Fe}, \mathrm{Ni}) \mathrm{S}$. Am. Mineral. 89, 39-50.

Evans H. T. (1970) Lunar Troilite: Crystallography. Science 167, 621-623.

Farrell S. P. and Fleet M. E. (2002) Phase separation in (Fe,Co) $)_{1-\mathrm{x}} \mathrm{S}$ monosulfide solidsolution below $450^{\circ} \mathrm{C}$, with consequences for coexisting pyrrhotite and pentlandite in magmatic sulfide deposits. Can. Mineral. 40, 33-46.

Francis C. A., Fleet M. E., Misra K. and Craig J. R. (1976) Orientation of exsolved pentlandite in natural and synthetic nickeliferious pyrrhotite. Am. Mineral. 61, 913920.

Gardner-Vandy K. G., Lauretta D. S. and McCoy T. J. (2013) A petrologic, thermodynamic and experimental study of brachinites: Partial melt residues of an $\mathrm{R}$ chondrite-like precursor. Geochim. Cosmochim. Acta 122, 36-57.

Geiger T. and Bischoff A. (1991) The CK chondrites - Conditions of parent body metamorphism. Meteoritics 26, 337.

Geiger T. and Bischoff A. (1995) Formation of opaque minerals in CK chondrites. Planet. Space Sci. 43, 485-498.

Gross J., Treiman A. H. and Connolly H. C. Jr. (2013) A new subgroup of amphibolebearing R-chondrites: Evidence from the new R-chondrite MIL 11207. Lunar Planet. Sci. XLIV. Lunar Planet. Inst., Houston. \# 2212 (abstr.).

Harries D. and Langenhorst F. (2013) The nanoscale mineralogy of Fe,Ni sulfides in pristine and metamorphosed $\mathrm{CM}$ and CM/CI-like chondrites: Tapping a petrogenetic record. Meteorit. Planet. Sci. 48, 879-903.

Hasegawa S., Müller T. G., Kawakami K., Kasuga T., Wada T., Ita Y., Takato N., Terada H., Fujiyoshi T. and Abe M. (2008) Albedo, size, surface characteristics of Hayabusa2 sample-return target 1621731999 JU3 from AKARI and Subaru observations. Publ. Astron. Soc. Japan 60, S399-S405.

Hawley J. E. and Haw V. A. (1957) Intergrowth of pentlandite and pyrrhotite. Econ. Geol. 56, 467-487.

Hewitt R. L. (1938) Experiments bearing on the relation of pyrrhotite to other sulphides. Econ. Geol. 33, 305-338. 
Hewins R. H., Connolly H. C. Jr., Lofgren G. E. and Libourel G. (2005) Experimental constraints on chondrule formation. In Chondrites and the protoplanetary disk. In ASP Conference Series 341 (eds. by A. N. Krot, E. R. D. Scott, and B. Reipurth). Astronomical Society of the Pacific, San Francisco. pp. 286-316.

Hirschmann M. M. (1991) Thermodynamics of multicomponent olivines and the solution properties of $(\mathrm{Ni}, \mathrm{Mg}, \mathrm{Fe})_{2} \mathrm{SiO}_{4}$ and $(\mathrm{Ca}, \mathrm{Mg}, \mathrm{Fe})_{2} \mathrm{SiO}_{4}$ olivines. Am. Mineral. 76, 1232 1248.

Huber H., Rubin A. E., Kallemeyn G. W. and Wasson J. T. (2006) Siderophile-element anomalies in CK carbonaceous chondrites: Implications for parent-body aqueous alteration and terrestrial weathering of sulfides. Geochim. Cosmochim. Acta 70, 4019-4037.

Hutchison R., Barber D. J., and Alexander C. M. O’D. (1987) The Semarkona meteorite: First recorded occurrence of smectite in an ordinary chondrite, and its implications. Geochim. Cosmochim. Acta 51, 1875-1882.

Jamsja N. and Ruzicka A. (2010) Shock and thermal history of Northwest Africa 4859, an annealed impact-melt breccia of LL chondrite parentage containing unusual igneous features and pentlandite. Meteorit. Planet. Sci. 45, 828-849.

Jenniskens P., Fries M. D., Yin Q-Z., Zolensky M., Krot A. N., Sanford S. A., Sears D., Beauford R., Ebel D. S., Friedrich J. M., Nagashima K., Wimpenny J., Yamakawa A., Nishiizumi K., Hamajima Y., Caffee M. W., Welten K. C., Laubenstein M., Davis A. M., Simon S. B., Heck P. R., Young E. D., Kohl I. E., Thiemens M. H., Nunn M. H., Mikouchi T., Hagiya K., Ohsumi K., Cahill T. A., Lawton J. A., Barnes D., Steele A., Rochette P., Verosub K. L., Gattacceca J., Cooper G., Glavin D. P., Burton A. S., Dworkin J. P., Elsila J. E., Pizzarello S., Ogliore R., Schmitt-Kopplin P., Harir M., Hertkorn N., Verchovsky A., Grady M., Nagao K., Okazaki R., Takechi H., Hiroi T., Smith K., Silber E. A., Brown P. G., Albers J., Klotz D., Hankey M., Matson R., Fries, J. A., Walker R. J., Puchtel I., Lee C-T. A., Erdman M. E., Eppich G. R., Roeske S., Gabelica Z., Lerche M., Nuevo M., Girten B. and Worden S. P. (the Sutter's Mill Meteorite Consortium) (2012) Radar-enabled recovery of the Sutter's Mill meteorite, a carbonaceous chondrite regolith breccia. Science 338, 1583-1587.

Jogo K., Nagashima K., Hutcheon I. D., Krot A. N. and Nakamura T. (2012) Heavily metamorphosed clasts from the CV chondrite breccias Mokoia and Yamato-86009. Meteorit. Planet. Sci. 47, 2251-2268.

Jones R. H., McCubbin F. M., Dreeland L., Guan Y., Burger P. V., and Shearer C. K. (2014) Phosphate minerals in LL chondrites: A record of the action of fluids during metamorphism on ordinary chondrite parent bodies. Geochim. Cosmochim. Acta 132, $120-140$.

Joswiak D. J. and Brownlee D. E. (2016) Possible igneous origins of sulfide-silicate assemblages found in comet Wild 2 and a giant cluster IDP of probably cometary origin. Lunar Planet. Sci. XLVII. Lunar Planet. Inst., Houston. \#1679 (abstr.).

Kallemeyn G. W., Rubin A. E. and Wasson J. T. (1991) The compositional classification of chondrites: V. The Karoonda (CK) group of carbonaceous chondrites. Geochim. Cosmochim. Acta 55, 881-892.

Keays R. R., Sewell D. K. B. and Mitchell R. H. (1981) Platinum and palladium minerals in upper mantle-derived lherzolites. Nature 294, 646-648. 
Kelly D. P. and Vaughan D. J. (1983) Pyrrhotite-pentlandite ore textures: A mechanistic approach. Mineral. Mag. 47, 453-463.

Karup-Moeller S. and Makovicky E. (1995) The Phase System Fe-Ni-S at $725{ }^{\circ} \mathrm{C}$, Neues Jahr. Mineral. Monatsh. 1, 1-10.

Kimura M., Grossman J. N. and Weisberg M. K. (2011) Fe-Ni metal and sulfide minerals in CM chondrites: An indicator for thermal history. Meteorit. Planet. Sci. 46, 431442.

Kosyakov V. I., Sinyakova E. F. and Shestakov V. A. (2003) Dependence of sulfur fugacity on the composition of phase associations in the Fe-FeS-NiS-Ni system at 873 K. Geochem. Int. 7, 660-669.

Kress V. (1997) Thermochemistry of sulfide liquids. 1. The system O-S-Fe at 1 bar. Contr. Mineral. Petrol. 127, 176-186

Kullerud G. (1963a) Thermal Stability of pentlandite. Can. Min. 7, 353-366.

Kullerud G. (1963b) The Fe-Ni-S system. Annu. Rep. Geophys. Lab. 1412, 175-189. Washington, DC.

Kullerud G., Yund R. A., Moh G. (1969) Phase relations in the Fe-Ni-S, Cu-Fe-S, and Cu-Ni-S systems. Econ. Geol. Monograph 4, 323-343.

Lauretta D. S., Lodders K. and Fegley Jr. B. (1998) Kamacite sulfurization in the solar nebula. Meteorit. Planet. Sci. 33, 821-833.

Lauretta D. S., Bartels A. E., Barucci M. A., Bierhaus E. B., Binzel R. P., Bottke W. F., Campins H., Chesley S. R., Clark B. C., Clark B. E., Cloutis E. A., Connolly H. C., Crombie M. K., Delbó M., Dworkin J. P., Emery J. P., Glavin D. P., Hamilton V. E., Hergenrother C. W., Johnson C. L., Keller L. P., Michel P., Nolan M. C., Sandford S. A., Scheeres D. J., Simon A. A., Sutter B. M., Vokrouhlický D. and Walsh K. J. (2015) The OSIRIS-REx target asteroid (101955) Bennu: Constraints on its physical, geological, and dynamical nature from astronomical observations. Meteorit. Planet. Sci. 50, 834-849.

Lindsley D. H. (1983) Pyroxene thermometry. Am. Mineral. 68, 477-493.

Lodders K., Palme H. and Gail H. -P. (2009) Abundances of the elements of the solar system. In Springer materials-The Landolt-Bornstein database (ed. J. E. Trümper). Springer, Berlin. pp. 560-598.

Merkle R. K. W. and Gruenwaldt G. V. (1986) Compositional variation of Co-rich pentlandite: Relation to the evolution of the upper zone of the western bushveld complex, South Africa. Can. Mineral. 24, 529-546.

McCanta M. C., Treiman A. H., Dyar M. D., Alexander C. M. O'D., Rumble III D. and Essene E. J. (2008) The LaPaz Icefield 04840 meteorite: Mineralogy, metamorphism, and origin of an amphibole- and biotite-bearing R chondrite. Geochim. Cosmochim. Acta 72, 5757-5780.

McCoy T. J., Scott E. R. D., Jones R. H., Keil K. and Taylor G. J. (1991) Composition of chondrule silicates in LL3-5 chondrites and implications for their nebular history and parent body metamorphism. Geochim. Cosmochim. Acta 55, 601-619.

McCoy T. J., Mittlefehldt D. W. and Wilson L. (2006) Asteroid differentiation. In Meteorites and the Early Solar System II (eds. D. S. Lauretta and H. Y. McSween). University of Arizona Press, Tucson. pp. 733-745. 
Miller K. E., Thompson M. S., Lauretta D. S. and Zega T. J. (2014) Conditions for formation of chalcopyrite in the Rumuruti chondrites. Lunar Planet. Sci. XLV. Lunar Planet. Inst., Houston. \#1461 (abstr.).

Miller K. E., Lauretta D. S., Connolly H. C., Nagashima K. and Domanik K. (2015) The nature of primitive $\mathrm{R}$ chondrite material: Characterization of an R3.2 clast in Mount Prestrud 95404. Lunar Planet. Sci. XLVI. Lunar Planet. Inst., Houston. \#2402 (abstr.).

Misra K. C. and Fleet M. E. (1973) The chemical compositions of synthetic and natural pentlandite assemblages. Econ. Geol. 68, 518-539.

Nakamura T., Noguchi T., Tanaka M., Zolensky M. E., Kimura M., Tsuchiyama A., Nakato A., Ogami T., Ishida H., Uesugi M., Yada T., Shirai K., Fujimura A., Okazaki R., Sandford S. A., Ishibashi Y., Abe M., Okada T., Ueno M., Mukai T., Yoshikawa M. and Kawaguchi J. (2011) Itokawa Dust Particles: A Direct Link Between S-Type Asteroids and Ordinary Chondrites. Science 333, 1113-1116.

Nakashima D., Ushikubo T., Kita N. T., Weisberg M. K., Zolensky M. E. and Ebel D. S. (2015) Late formation of a comet Wild 2 crystalline silicate particle Pyxie, inferred from Al-Mg chronology of plagioclase. Earth Planet. Sci. Lett. 410, 54-61.

Naldrett A. J., Craig J. R. and Kullerud G. (1967) The central portion of the Fe-Ni-S system and its bearing on pentlandite exsolution in iron-nickel sulfide ores. Econ Geol. 62, 826-847.

Naldrett A. J. (1969) A portion of the Fe-S-O and its application to sulfide ore magmas. $J$ Petrology 10, 171-201.

Naldrett A. J. (1989) Magmatic Sulphide Deposits. Oxford University Press, Oxford.

Naldrett A. J. (2004) Magmatic Sulfide Deposits: Geology, Geochemistry and Exploration. Spinger-Verlag, Berlin, Heidelberg.

Newhouse W. H. (1927) Equilibrium relations of pyrrhotite and pentlandite. Econ. Geol. 22, 283-300.

Ogliore R. C., Huss G. R., Nagashima K., Butterworth A. L., Gainsforth Z., Stodolna J., Westphal A. J., Joswiak D. and Tyliszczak T. (2012) Incorporation of a late-forming chondrule into comet Wild 2. Astrophys. J. Lett. 745, L19.

Raghavan V. (1998) Co-Fe-S (cobalt-iron-sulfur). J. Phase Equilib. 19, 264.

Raghavan V. (2004a) Fe-Ni-S (iron-nickel-sulfur). J. Phase Equilib. 25, 373-381.

Raghavan V. (2004b) Co-Fe-S (cobalt-iron-sulfur). J. Phase Equilib. Diff. 25, 365-367

Righter K. and Neff K. E. (2007) Temperature and oxygen fugacity constraints on CK and $\mathrm{R}$ chondrites and implications for water and oxidation in the early solar system. Polar Science 1, 25-44.

Rubin A. E. (2006) A relict-grain-bearing porphyritic olivine compound chondrule from LL3.0 Semarkona that experienced limited remelting. Meteorit. Planet. Sci. 41, 10271038.

Rubin A. E. (2014) Shock and annealing in the amphibole- and mica-bearing $\mathrm{R}$ chondrites. Meteorit. Planet. Sci. 49, 1057-1075.

Sack R. O. and Ghiorso M. S. (1989) Importance of considerations of mixing properties in establishing an internally consistent database: Thermochemistry of minerals in the system $\mathrm{Mg}_{2} \mathrm{SiO}_{4}-\mathrm{Fe}_{2} \mathrm{SiO}_{4}-\mathrm{SiO}_{2}$. Contrib. Mineral. Petrol. 102, 41-68.

Satterwhite C. and Righter K. (2008) Antarctic Meteorite Newsletter 31(1). 
Schrader D. L. and Lauretta D. S. (2010) High-temperature experimental analogs of primitive meteoritic metal-sulfide-oxide assemblages. Geochim. Cosmochim. Acta 74, 1719-1733.

Schrader D. L., Lauretta D. S., Connolly H. C. Jr., Goreva Y. S., Hill D. H., Domanik K., Berger E. L., Yang H. and Downs R. T. (2010a) Sulfide-rich metallic impact melts from chondritic parent bodies. Meteorit. Planet. Sci. 45, 743-758.

Schrader D. L., Connolly H. C. Jr. and Lauretta D. S. (2010b) On the nebular and aqueous signatures in the CR chondrites. Lunar Planet. Sci. XLI. Lunar Planet. Inst., Houston. \#1262 (abstr.).

Schrader D. L., Connolly H. C. Jr., Lauretta D. S., Nagashima K., Huss G. R., Davidson J. and Domanik K. J. (2013) The formation and alteration of the Renazzo-like carbonaceous chondrites II: Linking O-isotope composition and oxidation state of chondrule olivine. Geochim. Cosmochim. Acta 101, 302-327.

Schrader D. L., McCoy T. J. and Davidson J. (2014) Widespread evidence for hightemperature formation of pentlandite in chondrites. $37^{\text {th }}$ Symposium on Antarctic Meteorites, National Institute of Polar Research (abstr.).

Schrader D. L., Connolly H. C. Jr., Lauretta D. S., Zega T. J., Davidson J. and Domanik K. J. (2015a) The formation and alteration of the Renazzo-like carbonaceous chondrites III: Toward understanding the genesis of ferromagnesian chondrules. Meteorit. Planet. Sci. 50, 15-50.

Schrader D. L., McCoy T. J. and Davidson J. (2015b) Widespread evidence for hightemperature formation of pentlandite in chondrites. Lunar Planet. Sci. XLVI. Lunar Planet. Inst., Houston. \#1604 (abstr.).

Singerling S. A. and Brearley A. J. (2014) Iron-nickel sulfide exsolution textures in CM2 carbonaceous chondrites. Lunar Planet. Sci. XLV. Lunar Planet. Inst., Houston. \#2132 (abstr.).

Singerling S. A. and Brearley A. J. (2015) Primary nebular sulfides in CR and CM chondrites: Formation by sulfidization and crystallization. Lunar Planet. Sci. XLVI. Lunar Planet. Inst., Houston. \#1059 (abstr.).

Slater-Reynolds V. and McSween H. Y. (2005) Peak metamorphic temperatures in type 6 ordinary chondrites: An evaluation of pyroxene and plagioclase geothermometry. Meteorit. Planet. Sci. 40, 745-754.

Soltanieh M., Toguri J. M. and Sridhar R. (1999) The thermodynamics of the Fe-Co-S ternary system. Can. Metall. Quart. 38, 227-236.

Sugaki, A. and Kitakaze, A. (1998) High form pentlandite and its thermal stability. Am. Mineral. 83, 133-140.

Tachibana S., Abe M., Arakawa M., Fujimoto M., Iijima Y., Ishiguro M., Kitazato K., Kobayashi N., Namiki N., Okada T., Okazaki R., Sawada H., Sugita S., Takano Y., Tanaka S., Watanabe S., Yoshikawa M., Kuninaka H. and the Hayabusa2 Project Team. (2014) Hayabusa2: Scientific importance of samples returned from C-type near-Earth asteroid (162173) $1999 \mathrm{JU}_{3}$. Geochem. J. 48, 571-587.

Vaughan D. J. (2006) Sulfide mineralogy and geochemistry. Reviews in Mineralogy and Geochemistry, Vol. 61, pp. 714.

Weisberg M. K., McCoy T. J. and Krot A. N. (2006) Systematics and evaluation of meteorite classification. In Meteorites and the Early Solar System II (eds. D. S. Lauretta and H. Y. McSween). University of Arizona Press, Tucson. pp. 19-52. 
Zanda B., Bourot-Denise M., Perron C. and Hewins R. H. (1994) Origin and metamorphic redistribution of silicon, chromium, and phosphorus in the metal of chondrites. Science 265, 1846-1849.

Zolensky M. E. and Thomas K. L. (1995) Iron and iron-nickel sulfides in chondritic interplanetary dust particles. Geochim. Cosmochim. Acta 59, 4707-4712.

Zolensky M. and Le L. (2003) Iron-nickel sulfide compositional ranges in CM chondrites: No simple plan. Lunar Planet. Sci. XXXIV. Lunar Planet. Inst., Houston. \#1235 (abstr.).

Zolensky M., Nakamura-Messenger K., Rietmeijer F., Leroux H., Mikouchi T., Ohsumi K., Simon S., Grossman L., Stephan T., Weisberg M., Velbel M., Zega T., Stroud R., Tomeoka K., Ohnishi I., Tomioka N., Nakamura T., Matrajt G., Joswiak D., Brownlee D., Langenhorst F., Krot A., Kearsley A., Ishii H., Graham G., Dai Z. R., Chi M., Bradley J., Hagiya K., Gounelle M., Keller L. and Bridges J. (2008) Comparing Wild 2 particles to chondrites and IDPs. Meteorit. Planet. Sci. 43, 261272. 


\section{FIGURE CAPTIONS}

Figure 1. BSE images of sulfides showing the range of pentlandite textures observed. (a) Blocky pentlandite (pn) along the edge of the sulfide assemblage, along with pn blebs within pyrrhotite (po) in the CM2 Mighei (b) Islands of pyrite (py) within pentlandite in the CK4 ALH 85002. Magnetite (mag) is present within the sulfide grain. (c) Pentlandite blebs and 'flame' texture within po in the LL3.00 Semarkona. (d) Blocky pn and pn lamellae within po in the R3 MET 01149. Pentlandite lamellae with variable orientation across the sulfide grain indicate it is polycrystalline. Opaque assemblage also contains chromite (chr). (e) Well-formed pn lamellae along with poorly oriented pn blebs within po in the R6 MIL 11207. (f) Pentlandite along the edge of a sulfide grain dominated by po in the brachinite EET 99402. Where met $=$ Fe,Ni metal.

Figure 2. BSE images of uncommon sulfides observed. (a) Cobalt-rich pentlandite (Copn) in the CK4 Karoonda. (b) Molybdenite $\left(\mathrm{mo} ; \mathrm{MoS}_{2}\right)$ in association with pentlandite (pn) and pyrrhotite (po) in the LL4 Soko-Banja. (c) Chalcopyrite (ccp) surrounded by po and pn in the R5 LAP 03639.

Figure 3. (a) Ni vs. Co (wt.\%) composition of sulfides, and (b) for sulfides with less than 3 wt.\% Co for clarity. (c) Ni vs. Co (wt.\%) for sulfides from the brachinite, and CK and R chondrites. (d) Ni vs. Co (wt.\%) for sulfides from the CM and LL chondrites. With the exception of the CK chondrites, pyrrhotite is typically Co-poor while pentlandite is Corich. A marked increase in Co abundance occurs at $\sim 16 \mathrm{wt} . \% \mathrm{Ni}$.

Figure 4. Minimum metamorphic temperatures (with uncertainties) for samples of this study compared to the $610^{\circ} \mathrm{C}$ 'barrier' for dissolution or exsolution of pentlandite in mss. Pentlandite in samples that were not heated above $610^{\circ} \mathrm{C}$ is either primary or lowtemperature secondary. Pentlandite in samples heated above $610^{\circ} \mathrm{C}$ is high-temperature secondary. Temperatures for LEW 87009, Siena, Saint-Séverin, LAP 03639, and MIL 11207 were determined in this study. Temperatures are weighted means (with 2SE uncertainties) determined with two-pyroxene geothermometry; except MIL 11207, which is inferred from petrographic indicators such as FeNiS-veins. Temperature references for remaining samples are included in Table 1; samples with estimated minimum metamorphic temperature ranges are represented with multiple data points.

Figure 5. Fe-Ni-S ternary phase diagrams with sulfide data from all samples studied here. Sulfides from each group are consistent with phase diagrams over a range of temperatures, e.g., some sulfides in the $\mathrm{CM}$ chondrites are consistent with equilibration temperatures of (a) $100-135^{\circ} \mathrm{C}$, while others of (b) $600^{\circ} \mathrm{C}$. Representative isothermal phase diagrams are given for the (c) $\mathrm{CK}$ chondrites $\left(230^{\circ} \mathrm{C}\right),(\mathrm{d}) \mathrm{LL}$ chondrites $\left(600^{\circ} \mathrm{C}\right)$, (e) $\mathrm{R}$ chondrites $\left(400^{\circ} \mathrm{C}\right)$ and (f) the brachinite $\left(400^{\circ} \mathrm{C}\right)$. Where po = pyrrhotite, pn = pentlandite, mss = monosulfide solid solution, $\mathrm{hz}=$ heazlewoodite $\left(\mathrm{Ni}_{3} \mathrm{~S}_{2}\right)$, vs = vaesite $\left(\mathrm{NiS}_{2}\right)$, vio $=$ violarite $\left(\mathrm{Ni}_{3} \mathrm{~S}_{4}\right)$. Phase diagrams adapted from Raghavan (2004a); original data from Naldrett (1989) $\left(100-135^{\circ} \mathrm{C}\right)$, Misra and Fleet $(1973)\left(230^{\circ} \mathrm{C}\right)$, Craig et al. $(1968)\left(400^{\circ} \mathrm{C}\right)$ and Kosyakov et al. $(2003)\left(600^{\circ} \mathrm{C}\right)$. See EA-3 for all phase diagrams. 
Table 1. List of samples and parent body thermal history

\begin{tabular}{|c|c|c|c|c|c|c|c|c|}
\hline Meteorite & Type & Fall/Find & Weathering & $\begin{array}{c}\text { Minimum } \\
\text { Metamorphic } \\
\text { Temperature } \\
\text { (This Study) } \\
\text { weighted } \\
\text { mean } \pm 2 \sigma\end{array}$ & $\begin{array}{c}\text { Method } \\
\text { (This Study) }\end{array}$ & $\begin{array}{c}\text { Metamorphic } \\
\text { Temperature } \\
\text { (Literature) }\end{array}$ & Method (Literature) & Reference \\
\hline CM chondrite & & & & & & & & \\
\hline $\begin{array}{c}\text { Mighei USNM 3483-3 } \\
\text { C chondrite (CM-like breccia) }\end{array}$ & $\mathrm{CM} 2$ & Fall & Wo & & & $<220^{\circ} \mathrm{C}$ & graphite-ordering & a \\
\hline $\begin{array}{l}\text { Sutter's Mill } \\
\text { CK chondrites }\end{array}$ & C & Fall & W0 & & & $\sim 150-500^{\circ} \mathrm{C}$ & various & $\mathrm{b}$ \\
\hline ALH 85002,87 & CK4 & Find & A & & & $647-867^{\circ} \mathrm{C}$ & Fe-Mg ol diffusion & c \\
\hline Karoonda USNM2428-3 & CK4 & Fall & wo & & & $647-867^{\circ} \mathrm{C}$ & Fe-Mg ol diffusion & c \\
\hline LAR 06868 & CK5 & Find & $A / B$ & & & $647-867^{\circ} \mathrm{C}$ & Fe-Mg ol diffusion & c \\
\hline LEW 87009 & CK6 & Find & $\mathrm{Ae}$ & $740 \pm 38^{\circ} \mathrm{C}$ & two-pyx & $800-1000^{\circ} \mathrm{C}$ & two-pyx & $d$ \\
\hline LL chondrites & & & & & & & & \\
\hline Semarkona USNM1805-17 & LL3.00 & Fall & Wo & & & $<220^{\circ} \mathrm{C}$ & graphite-ordering & a \\
\hline Soko-Banja USNM3078-1 & LL4 & Fall & Wo & & & $>600^{\circ} \mathrm{C}$ & Fe-Mg ol diffusion & e \\
\hline Siena USNM3070-3 & LL5 & Fall & Wo & $867 \pm 28^{\circ} \mathrm{C}$ & two-pyx & $677-727^{\circ} \mathrm{C}$ & ol-chr & $f$ \\
\hline Saint-Séverin USNM2608-3 & LL6 & Fall & Wo & $899 \pm 70^{\circ} \mathrm{C}$ & two-pyx & $897 \pm 104^{\circ} \mathrm{C}$ & two-pyx & $\mathrm{g}$ \\
\hline$R$ chondrites & & & & & & & & \\
\hline MET 01149,27 & R3 & Find & A & & & & & \\
\hline LAP 031275,2 & $\mathrm{R} 4^{2}$ & Find & $\mathrm{B} / \mathrm{C}$ & & & & & \\
\hline LAP 03639,2 & $\mathrm{R} 5^{2}$ & Find & $\mathrm{A} / \mathrm{B}$ & $853 \pm 62^{\circ} \mathrm{C}$ & two-pyx & & & \\
\hline MIL 11207,2 & $\mathrm{R} 6$ & Find & $\mathrm{Ce}$ & $\geq 950^{\circ} \mathrm{C}$ & Fe-Ni-S veins ${ }^{3}$ & $700-900^{\circ} \mathrm{C}$ & dehydration & $\mathrm{h}$ \\
\hline LAP 04840,4 & R6 & Find & $A / B$ & & & $670 \pm 60^{\circ} \mathrm{C}$ & amph-plag & $\mathrm{i}$ \\
\hline Brachinite & & & & & & & & \\
\hline EET 99402,6 & Brachinite & Find & B & & & $980 \pm 16^{\circ} \mathrm{C}$ & ol-chr & j \\
\hline
\end{tabular}

(1) Sutter's Mill thin section from stone SM8 (19.05 grams), 'post-rain' stone recovered April $27^{\text {th }}, 2012$.

(2) Since LAP 03639 is more equilibrated than LAP 031275, we revise their classifications with LAP 03639 now considered an R5, and LAP 031275 an F

(3) temperature of $\mathrm{Fe}, \mathrm{Ni}$-FeS eutectic $~ 950^{\circ} \mathrm{C}$ (Kullerud, 1963b; McCoy et al., 2006).

Where two-pyx = two-pyroxene equilibration temperature; O-isotopes = temperature determined by O-isotope equilibration;

$\mathrm{Fe}-\mathrm{Mg}$ ol diffusion = Fe-Mg diffusion in olivine; ol-chr = olivine-chromite equilibration temperature; amph-plag = amphibole-plagioclase thermometry

(a) Busemann et al. (2007); (b) Jenniskens et al. (2012); (c) Chaumard and Devouard (2016); (d) Geiger and Bischoff (1991); (e) McCoy et al. (1991);

(f) Kessel et al. (2007); (g) Slater-Reynolds and McSween (2005); (h) Rubin (2014); (i) McCanta et al. (2008); (j) Gardner-Vandy et al. (2013). 
Table 2. Representative sulfide compositional analyses (wt.\%)

\begin{tabular}{|c|c|c|c|c|c|c|c|c|c|c|c|c|c|c|}
\hline $\begin{array}{l}\text { Sample } \\
\text { Type }\end{array}$ & $\begin{array}{l}\text { Mighei } \\
\text { CM2 }\end{array}$ & $\begin{array}{l}\text { Mighei } \\
\text { CM2 }\end{array}$ & $\begin{array}{c}\text { ALH } 85002 \\
\text { CK4 }\end{array}$ & $\begin{array}{c}\text { ALH } 85002 \\
\text { CK4 }\end{array}$ & $\begin{array}{c}\text { Karoonda } \\
\text { CK4 }\end{array}$ & $\begin{array}{c}\text { Semarkona } \\
\text { LL3.00 }\end{array}$ & $\begin{array}{c}\text { Semarkona } \\
\text { LL3.00 }\end{array}$ & $\begin{array}{c}\text { MET } 01149 \\
\text { R3 }\end{array}$ & $\begin{array}{c}\text { MET } 01149 \\
\text { R3 }\end{array}$ & $\begin{array}{c}\text { MET } 01149 \\
\text { R3 }\end{array}$ & $\begin{array}{c}\text { MIL } 11207 \\
\text { R6 }\end{array}$ & $\begin{array}{c}\text { MIL } 11207 \\
\text { R6 }\end{array}$ & $\begin{array}{c}\text { EET } 99402 \\
\text { Brach }\end{array}$ & $\begin{array}{c}\text { EET } 99402 \\
\text { Brach }\end{array}$ \\
\hline Area & Mx4 & Ch3 & Ch1 & Ch1 & Ch3 & Ch1 & Ch1 & M5 & M5 & Ch3 & & & & \\
\hline Grain & OA8 & OA10 & OA3 & OA3 & OA10 & OA8 & OA8 & & & A5 & OA5 & OA5 & OA1 & OA1 \\
\hline Mineral & po & pn & py & pn & Co-pn & po & pn & po & $\mathrm{pn}$ & $\mathrm{ccp}$ & po & pn & po & pn \\
\hline $\mathrm{Fe}$ & 60.9 & 34.7 & 43.1 & 27.2 & 13.1 & 62.1 & 47.6 & 61.6 & 35.4 & 30.2 & 60.5 & 32.1 & 62.7 & 39.9 \\
\hline $\mathrm{Ni}$ & 0.64 & 32.1 & 0.84 & 38.0 & 31.0 & 0.34 & 17.8 & 0.17 & 30.3 & 0.25 & 0.89 & 32.7 & bdl & 19.6 \\
\hline $\mathrm{P}$ & bdl & bdl & bdl & bdl & bdl & bdl & bdl & bdl & bdl & bdl & bdl & bdl & bdl & bdl \\
\hline S & 38.0 & 32.4 & 53.3 & 33.9 & 42.7 & 37.4 & 34.1 & 38.1 & 33.2 & 35.3 & 39.2 & 34.3 & 36.7 & 34.0 \\
\hline $\mathrm{Cr}$ & bdl & bdl & bdl & bdl & bdl & 0.04 & 0.05 & bdl & bdl & bdl & bdl & bdl & bdl & bdl \\
\hline Co & bdl & 0.62 & 2.23 & 0.76 & 13.1 & bdl & 0.30 & bdl & 1.07 & bdl & bdl & 0.86 & bdl & 6.16 \\
\hline $\mathrm{Si}$ & bdl & bdl & bdl & bdl & bdl & bdl & bdl & bdl & bdl & bdl & bdl & bdl & bdl & bdl \\
\hline Al & bdl & bdl & bdl & bdl & bdl & bdl & bdl & bdl & bdl & bdl & bdl & bdl & bdl & bdl \\
\hline $\mathrm{Cu}$ & 0.09 & bdl & bdl & bdl & bdl & 0.09 & 0.16 & bdl & 0.11 & 32.8 & bdl & bdl & bdl & bdl \\
\hline Total & 99.6 & 100.0 & 99.5 & 99.9 & 99.8 & 99.9 & 100.0 & 99.9 & 100.1 & 98.6 & 100.5 & 100.0 & 99.4 & 99.7 \\
\hline
\end{tabular}

Where $\mathrm{po}=$ pyrrhotite $; \mathrm{pn}=$ pentlandite $; \mathrm{py}=$ pyrite $;$ Co-pn = Co-rich pentlandite $; \mathrm{ccp}=$ chalcopyrite .

With the exception of uncommon sulfides (Co-pn and ccp), data here are typically pairs of coexisting low- and high-Ni sulfides (po-pn and py-pn) within individual sulfide grains. Standards and detection limits (in wt.\%) are troilite for $\mathrm{Fe}(0.05)$ and $\mathrm{S}(0.01)$, schreibersite for $\mathrm{P}(0.02)$, chromium metal for $\mathrm{Cr}(0.03)$, cobalt metal for Co (0.05),

silicon metal for $\mathrm{Si}(0.03)$, aluminium for $\mathrm{Al}(0.02)$, and copper metal for $\mathrm{Cu}(0.08)$. 


\begin{tabular}{|c|c|c|c|c|c|c|c|c|}
\hline Sample & \multicolumn{2}{|c|}{ LEW 87009} & \multicolumn{2}{|c|}{ Siena } & \multicolumn{2}{|c|}{ Saint-Séverin } & \multicolumn{2}{|c|}{ LAP 03639} \\
\hline Type & \multicolumn{2}{|c|}{ CK6 } & \multicolumn{2}{|c|}{ LL5 } & \multicolumn{2}{|c|}{ LL6 } & \multicolumn{2}{|c|}{ R5 } \\
\hline Area & \multicolumn{2}{|c|}{$M \times 4$} & \multicolumn{2}{|c|}{$M \times 3$} & \multicolumn{2}{|c|}{$M \times 3$} & \multicolumn{2}{|c|}{ Clast } \\
\hline Mineral & LCP & $\mathrm{HCP}$ & LCP & $\mathrm{HCP}$ & LCP & $\mathrm{HCP}$ & LCP & $\mathrm{HCP}$ \\
\hline $\mathrm{SiO}_{2}$ & 54.3 & 52.8 & 54.9 & 54.3 & 54.4 & 53.5 & 54.1 & 53.5 \\
\hline $\mathrm{TiO}_{2}$ & bdl & 0.09 & 0.12 & 0.41 & 0.14 & 0.43 & bdl & 0.23 \\
\hline $\mathrm{Al}_{2} \mathrm{O}_{3}$ & 0.27 & 2.38 & 0.18 & 0.44 & 0.21 & 0.52 & 0.43 & 0.83 \\
\hline $\mathrm{Cr}_{2} \mathrm{O}_{3}$ & bdl & 0.24 & 0.07 & 0.74 & 0.14 & 0.84 & 0.48 & 0.49 \\
\hline $\begin{array}{l}\mathrm{FeO} \\
\mathrm{MnO}\end{array}$ & $\begin{array}{l}17.6 \\
0.25\end{array}$ & $\begin{array}{l}7.38 \\
0.09\end{array}$ & $\begin{array}{l}15.5 \\
0.50\end{array}$ & $\begin{array}{l}5.55 \\
0.24\end{array}$ & $\begin{array}{l}15.8 \\
0.49\end{array}$ & $\begin{array}{l}5.86 \\
0.22\end{array}$ & $\begin{array}{l}14.9 \\
0.22\end{array}$ & $\begin{array}{l}5.87 \\
0.14\end{array}$ \\
\hline $\mathrm{MgO}$ & 27.1 & 14.4 & 27.7 & 16.5 & 28.2 & 16.7 & 28.5 & 16.2 \\
\hline $\mathrm{CaO}$ & 0.36 & 22.7 & 0.48 & 21.7 & 0.84 & 21.4 & 0.65 & 22.6 \\
\hline $\mathrm{NiO}$ & 0.33 & 0.13 & 0.08 & bdl & bdl & bdl & bdl & bdl \\
\hline $\mathrm{Na}_{2} \mathrm{O}$ & bdl & 0.84 & bdl & 0.59 & bdl & 0.59 & bdl & 0.56 \\
\hline $\mathrm{P}_{2} \mathrm{O}_{5}$ & bdl & bdl & bdl & bdl & bdl & bdl & bdl & 0.09 \\
\hline Total & 100.2 & 101.1 & 99.6 & 100.5 & 100.2 & 100.0 & 99.2 & 100.5 \\
\hline Closure & \multirow{2}{*}{\multicolumn{2}{|c|}{$741 \pm 50^{\circ} \mathrm{C}$}} & \multirow{2}{*}{\multicolumn{2}{|c|}{$798 \pm 68^{\circ} \mathrm{C}$}} & \multirow{2}{*}{\multicolumn{2}{|c|}{$897 \pm 102^{\circ} \mathrm{C}$}} & \multirow{2}{*}{\multicolumn{2}{|c|}{$846 \pm 80^{\circ} \mathrm{C}$}} \\
\hline $\begin{array}{l}\text { Temperature } \\
\qquad( \pm 2 \sigma)\end{array}$ & & & & & & & & \\
\hline
\end{tabular}

Representative analyses and individual mineral pair closure temperatures only.

Weighted means of closure temperatures are given in Fig. 4.

$\mathrm{Ch}=$ chondrule; $\mathrm{Mx}=$ matrix LCP = low-calcium pyroxene; $\mathrm{HCP}=$ high-calcium pyroxene.

Standards and detection limits (in wt.\%) are diopside for Mg (0.01) and Si (0.02), VG-A99 USNM 113498 for Na (0.03), Kakanui hornblende for $\mathrm{Al}$ (0.01), $\mathrm{Ti}(0.05)$, and $\mathrm{K}(0.02)$, Rockport fayalite for $\mathrm{Fe}(0.04)$, fluorapatite for $\mathrm{Ca}(0.02)$ 
Table 4. Major and minor element compositional averages and ranges of sulfides (wt.\%).

\begin{tabular}{|c|c|c|c|c|c|c|c|c|c|}
\hline & $\mathrm{Fe}$ & $\mathbf{S}$ & $\mathrm{Ni}$ & Co & $\mathrm{Cr}$ & $\mathbf{P}$ & $\mathrm{Cu}$ & Total & \# Analyses \\
\hline \multicolumn{10}{|l|}{ CM chondrites } \\
\hline Pyrrhotite & $\begin{array}{c}61.0 \pm 2.0 \\
(55.1-63.7)\end{array}$ & $\begin{array}{c}35.6 \pm 0.9 \\
(35.6-39.1)\end{array}$ & $\begin{array}{l}1.37 \pm 2.27 \\
(0.26-9.67)\end{array}$ & bdl & bdl & bdl & $\begin{array}{l}0.01 \pm 0.03 \\
(\mathrm{bdl}-0.10)\end{array}$ & $100.0 \pm 1.1$ & 16 \\
\hline Pentlandite & $\begin{array}{c}34.9 \pm 3.4 \\
(32.0-43.0)\end{array}$ & $\begin{array}{c}32.3 \pm 1.0 \\
(30.6-34.6)\end{array}$ & $\begin{array}{c}31.5 \pm 3.6 \\
(22.2-35.0)\end{array}$ & $\begin{array}{c}0.71 \pm 0.21 \\
(0.26-1.06)\end{array}$ & $\begin{array}{l}0.01 \pm 0.02 \\
\text { (bdl-0.06) }\end{array}$ & $\begin{array}{l}0.00 \pm 0.01 \\
\text { (bdl-0.04) }\end{array}$ & $\begin{array}{l}0.01 \pm 0.03 \\
\text { (bdl-0.11) }\end{array}$ & $99.5 \pm 0.8$ & 34 \\
\hline \multicolumn{10}{|l|}{ CK chondrites } \\
\hline Pyrrhotite/Pyrite & $\begin{array}{c}45.6 \pm 3.4 \\
(38.0-57.3)\end{array}$ & $\begin{array}{c}50.1 \pm 6.1 \\
(37.7-54.8)\end{array}$ & $\begin{array}{c}3.03 \pm 4.53 \\
(0.08-15.7)\end{array}$ & $\begin{array}{l}1.02 \pm 0.61 \\
\text { (bdl-2.23) }\end{array}$ & $\begin{array}{l}0.01 \pm 0.02 \\
(\mathrm{bdl}-0.08)\end{array}$ & $\begin{array}{l}0.01 \pm 0.02 \\
\text { (bdl-0.08) }\end{array}$ & $\begin{array}{l}0.01 \pm 0.04 \\
\text { (bdl-0.14) }\end{array}$ & $99.9 \pm 1.0$ & 53 \\
\hline Pentlandite & $\begin{array}{c}28.0 \pm 3.2 \\
(21.0-41.4)\end{array}$ & $\begin{array}{c}34.0 \pm 2.0 \\
(30.9-43.0)\end{array}$ & $\begin{array}{c}36.9 \pm 4.9 \\
(17.3-41.8)\end{array}$ & $\begin{array}{l}0.70 \pm 0.46 \\
(\mathrm{bdl}-4.10)\end{array}$ & $\begin{array}{l}0.02 \pm 0.04 \\
(\mathrm{bdl}-0.24)\end{array}$ & $\begin{array}{l}0.00 \pm 0.01 \\
(\mathrm{bdl}-0.05)\end{array}$ & $\begin{array}{l}0.03 \pm 0.05 \\
(\mathrm{bdl}-0.27)\end{array}$ & $99.6 \pm 0.9$ & 135 \\
\hline $\begin{array}{l}\text { Co-rich } \\
\text { pentlandite }\end{array}$ & $\begin{array}{c}13.1 \pm 0.4 \\
(12.6-13.6)\end{array}$ & $\begin{array}{c}42.1 \pm 0.6 \\
(40.9-42.7)\end{array}$ & $\begin{array}{c}30.7 \pm 0.41 \\
(30.2-31.4)\end{array}$ & $\begin{array}{c}13.2 \pm 0.5 \\
(12.4-13.8)\end{array}$ & bdl & bdl & bdl & $99.1 \pm 0.5$ & 7 \\
\hline Chalcopyrite & $\begin{array}{c}29.9 \pm 0.3 \\
(29.5-30.1)\end{array}$ & $\begin{array}{c}35.3 \pm 0.3 \\
(35.0-35.6)\end{array}$ & $\begin{array}{c}0.17 \pm 0.04 \\
(0.12-0.19)\end{array}$ & bdl & $\begin{array}{l}0.04 \pm 0.06 \\
\text { (bdl-0.11) }\end{array}$ & $\begin{array}{l}0.01 \pm 0.02 \\
\text { (bdl-0.03) }\end{array}$ & $\begin{array}{c}32.8 \pm 0.4 \\
(32.4-33.2)\end{array}$ & $98.2 \pm 0.2$ & 3 \\
\hline \multicolumn{10}{|c|}{ LL3.00 chondrite (Semarkona) } \\
\hline Pyrrhotite & $\begin{array}{c}62.1 \pm 1.8 \\
(51.3-63.8)\end{array}$ & $\begin{array}{c}37.0 \pm 0.5 \\
(34.1-38.1)\end{array}$ & $\begin{array}{l}0.47 \pm 2.23 \\
\text { (bdl-15.3) }\end{array}$ & $\begin{array}{l}0.00 \pm 0.03 \\
(\mathrm{bdl}-0.23)\end{array}$ & $\begin{array}{l}0.04 \pm 0.04 \\
(\mathrm{bdl}-0.21)\end{array}$ & $\begin{array}{l}0.00 \pm 0.01 \\
\text { (bdl-0.05) }\end{array}$ & $\begin{array}{l}0.00 \pm 0.02 \\
(\mathrm{bdl}-0.10)\end{array}$ & $99.6 \pm 0.7$ & 47 \\
\hline Pentlandite & $\begin{array}{c}47.8 \pm 0.8 \\
(46.7-50.1)\end{array}$ & $\begin{array}{c}33.9 \pm 0.5 \\
(32.7-34.7)\end{array}$ & $\begin{array}{c}17.6 \pm 0.6 \\
(16.0-18.5)\end{array}$ & $\begin{array}{l}0.28 \pm 0.12 \\
(\mathrm{bdl}-0.46)\end{array}$ & $\begin{array}{l}0.03 \pm 0.05 \\
(\mathrm{bdl}-0.19)\end{array}$ & bdl & $\begin{array}{l}0.11 \pm 0.08 \\
(\mathrm{bdl}-0.29)\end{array}$ & $99.8 \pm 0.9$ & 18 \\
\hline \multicolumn{10}{|l|}{ LL 4-6 chondrites } \\
\hline Pyrrhotite & $\begin{array}{c}62.5 \pm 1.0 \\
(57.4-64.3)\end{array}$ & $\begin{array}{c}37.0 \pm 0.6 \\
(34.5-38.1)\end{array}$ & $\begin{array}{l}0.08 \pm 0.50 \\
\text { (bdl-5.57) }\end{array}$ & bdl & $\begin{array}{l}0.02 \pm 0.07 \\
\text { (bdl-0.49) }\end{array}$ & $\begin{array}{l}0.00 \pm 0.00 \\
\text { (bdl-0.03) }\end{array}$ & $\begin{array}{l}0.00 \pm 0.03 \\
\text { (bdl-0.36) }\end{array}$ & $99.7 \pm 1.0$ & 139 \\
\hline Pentlandite & $\begin{array}{c}44.2 \pm 2.0 \\
(39.7-49.3)\end{array}$ & $\begin{array}{c}33.8 \pm 0.5 \\
(31.9-34.9)\end{array}$ & $\begin{array}{c}20.1 \pm 1.7 \\
(16.2-23.7)\end{array}$ & $\begin{array}{l}0.60 \pm 0.58 \\
\text { (bdl-2.41) }\end{array}$ & $\begin{array}{l}0.01 \pm 0.07 \\
\text { (bdl-0.41) }\end{array}$ & $\begin{array}{l}0.00 \pm 0.01 \\
\text { (bdl-0.03) }\end{array}$ & $\begin{array}{l}0.14 \pm 0.22 \\
\text { (bdl-1.19) }\end{array}$ & $98.8 \pm 0.6$ & 47 \\
\hline \multicolumn{10}{|l|}{$\mathrm{R}$ chondrites } \\
\hline Pyrrhotite & $\begin{array}{c}59.0 \pm 3.3 \\
(48.2-64.2)\end{array}$ & $\begin{array}{c}38.5 \pm 0.8 \\
(34.7-40.5)\end{array}$ & $\begin{array}{c}2.2 \pm 3.1 \\
(\mathrm{bdl}-15.3)\end{array}$ & $\begin{array}{l}0.01 \pm 0.07 \\
\text { (bdl-0.90) }\end{array}$ & $\begin{array}{l}0.02 \pm 0.05 \\
\text { (bdl-0.28) }\end{array}$ & $\begin{array}{l}0.01 \pm 0.03 \\
\text { (bdl-0.31) }\end{array}$ & $\begin{array}{l}0.02 \pm 0.08 \\
\text { (bdl-0.65) }\end{array}$ & $99.8 \pm 0.8$ & 217 \\
\hline Pentlandite & $\begin{array}{c}33.5 \pm 2.7 \\
(27.1-54.8)\end{array}$ & $\begin{array}{c}33.8 \pm 0.9 \\
(22.7-35.7)\end{array}$ & $\begin{array}{c}31.9 \pm 2.5 \\
(19.1-38.6)\end{array}$ & $\begin{array}{c}0.92 \pm 0.16 \\
(0.40-1.55)\end{array}$ & $\begin{array}{l}0.02 \pm 0.05 \\
(\mathrm{bdl}-0.30)\end{array}$ & $\begin{array}{l}0.01 \pm 0.06 \\
(\mathrm{bdl}-0.73)\end{array}$ & $\begin{array}{l}0.07 \pm 0.35 \\
(\mathrm{bdl}-4.26)\end{array}$ & $100.2 \pm 0.7$ & 201 \\
\hline Chalcopyrite & $\begin{array}{c}30.1 \pm 0.2 \\
(30.0-30.2)\end{array}$ & $\begin{array}{c}35.2 \pm 0.3 \\
(35.0-35.3)\end{array}$ & $\begin{array}{c}0.21 \pm 0.06 \\
(0.16-0.25)\end{array}$ & bdl & bdl & bdl & $\begin{array}{c}32.7 \pm 0.2 \\
(32.5-32.8)\end{array}$ & $98.1 \pm 0.7$ & 2 \\
\hline \multicolumn{10}{|l|}{ Brachinite } \\
\hline Pyrrhotite & $\begin{array}{c}61.3 \pm 2.4 \\
(50.3-62.7)\end{array}$ & $\begin{array}{c}36.8 \pm 0.7 \\
(33.9-37.3)\end{array}$ & $\begin{array}{l}0.51 \pm 2.41 \\
\text { (bdl-11.6) }\end{array}$ & $\begin{array}{l}0.13 \pm 0.62 \\
(\mathrm{bdl}-2.96)\end{array}$ & $\begin{array}{l}0.05 \pm 0.09 \\
\text { (bdl-0.32) }\end{array}$ & bdl & bdl & $98.8 \pm 0.4$ & 23 \\
\hline Pentlandite & $\begin{array}{c}39.9 \pm 0.5 \\
(39.4-40.5)\end{array}$ & $\begin{array}{c}34.2 \pm 0.3 \\
(33.9-34.6)\end{array}$ & $\begin{array}{c}19.3 \pm 0.3 \\
(18.9-19.6)\end{array}$ & $\begin{array}{c}5.92 \pm 0.32 \\
(5.53-6.19)\end{array}$ & bdl & bdl & bdl & $99.4 \pm 0.2$ & 4 \\
\hline
\end{tabular}

Average \pm one standard deviation, (minimum-maximum).

Standards and detection limits (in wt.\%) are troilite for $\mathrm{Fe}(0.05)$ and $\mathrm{S}(0.01)$, schreibersite for $\mathrm{P}(0.02)$, chromium metal for $\mathrm{Cr}(0.03)$, cobalt metal for $\mathrm{Co}(0.05)$, silicon metal for $\mathrm{Si}(0.03)$, aluminium for $\mathrm{Al}(0.02)$, and copper metal for $\mathrm{Cu}(0.08)$.

$\mathrm{bdl}=$ below detection limit. 

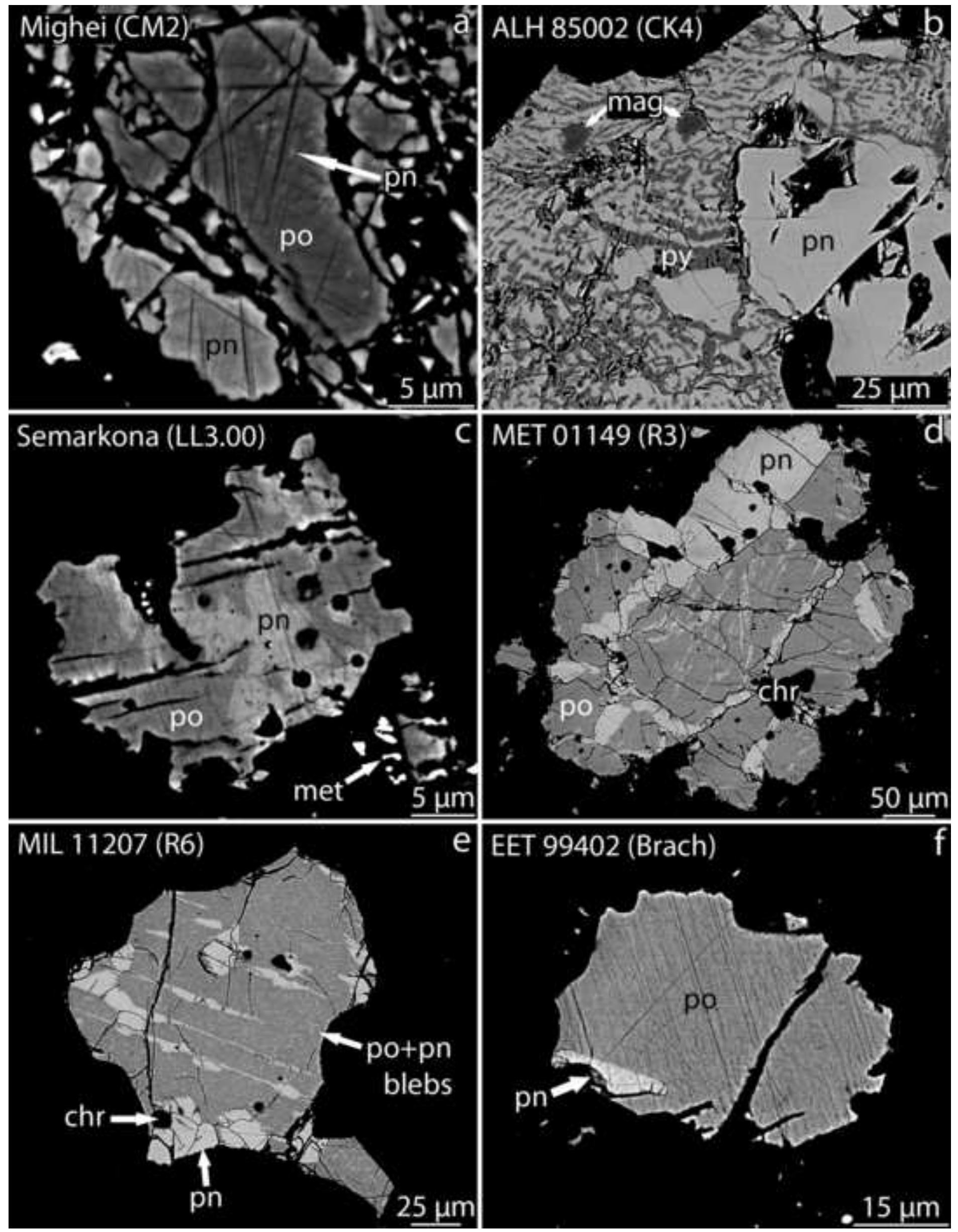
Figure 2
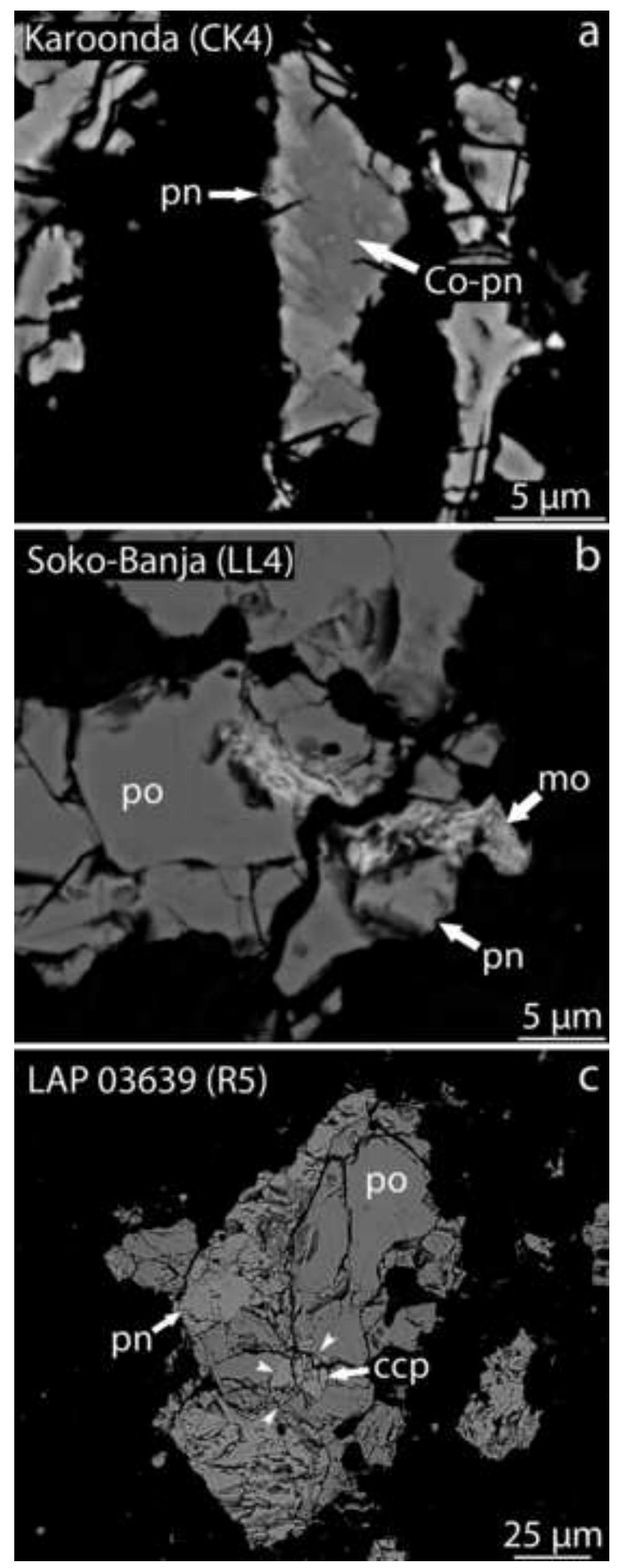
Ni (wt. \%)

Ni (wt. \%)
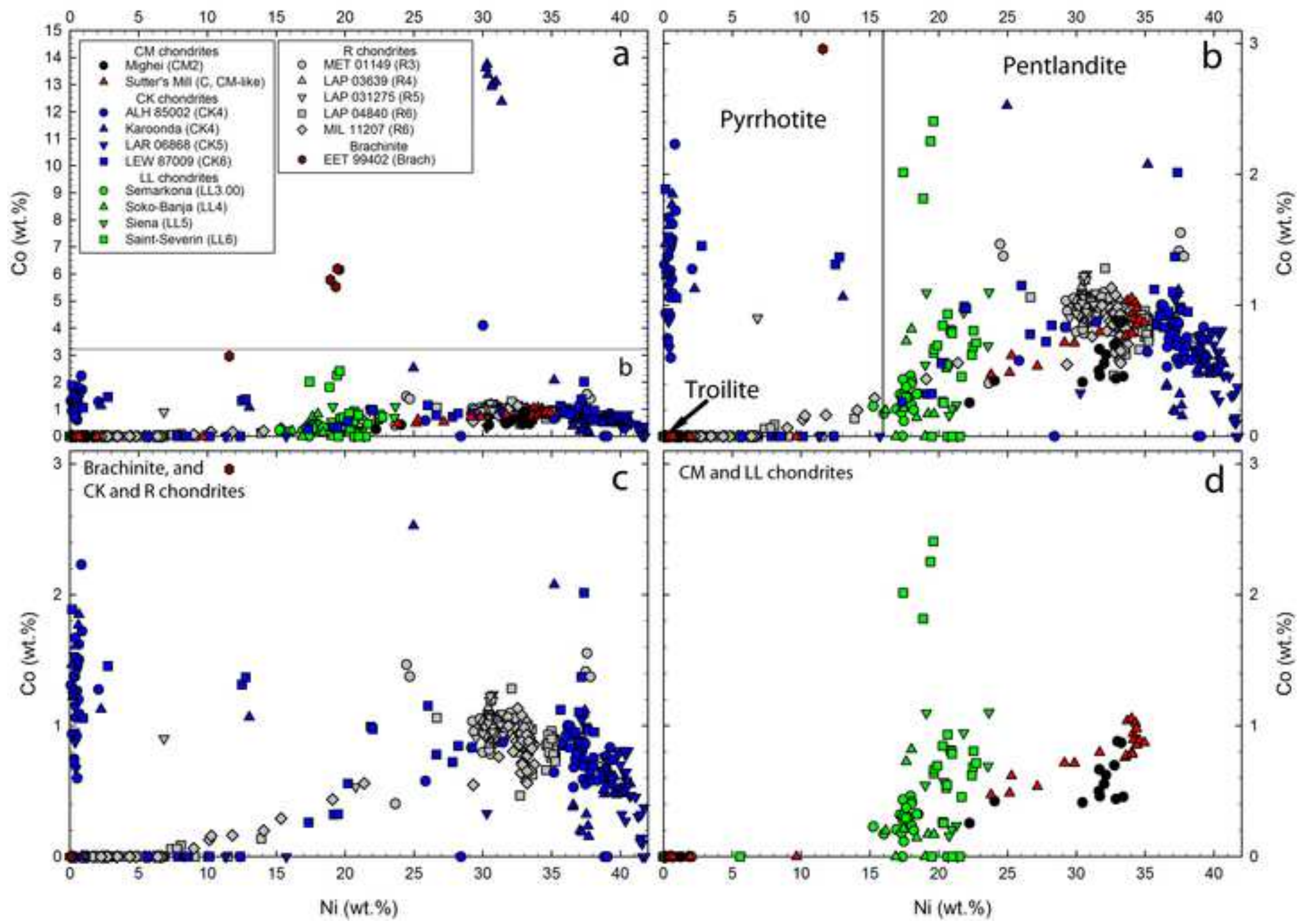


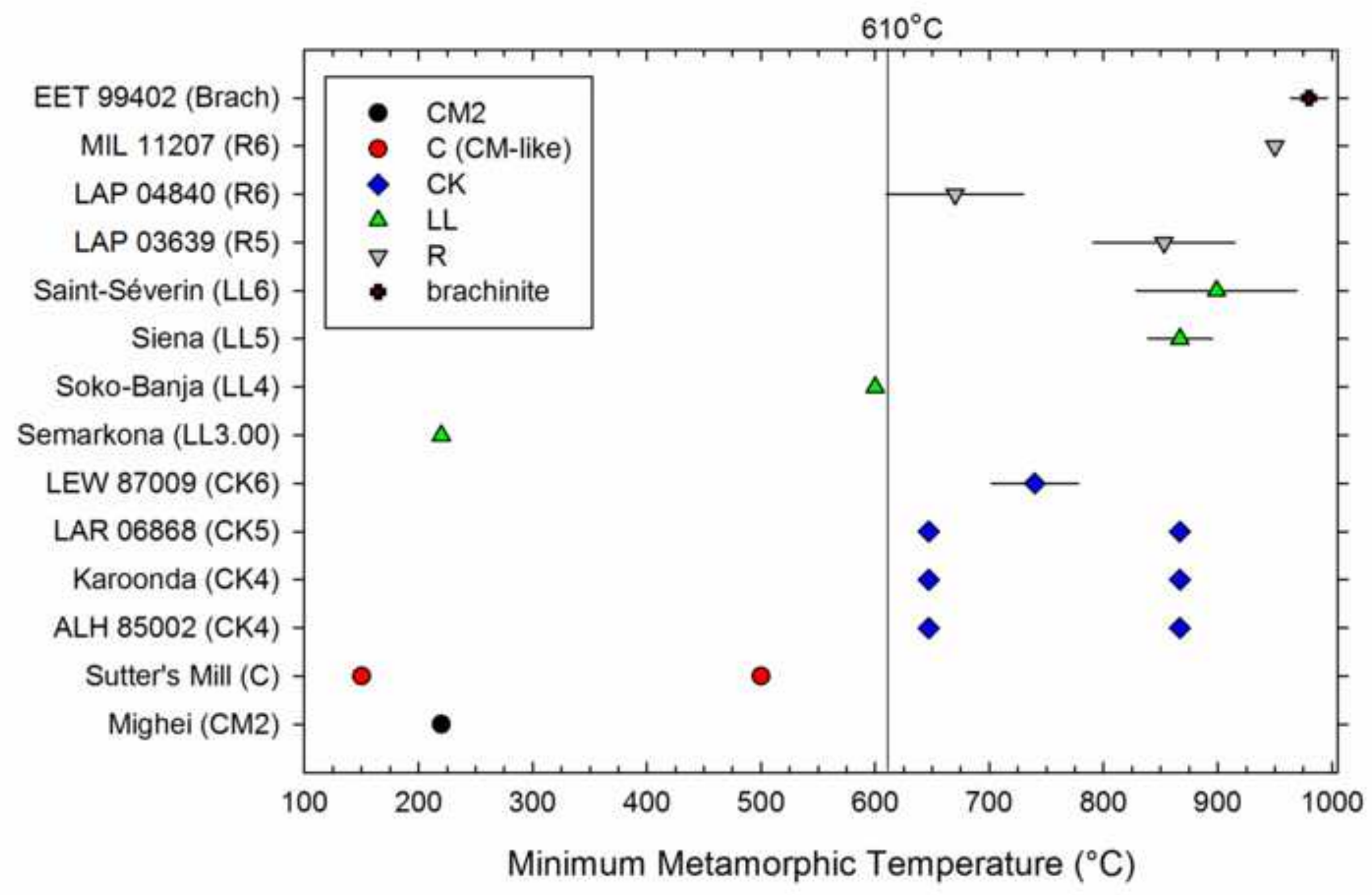




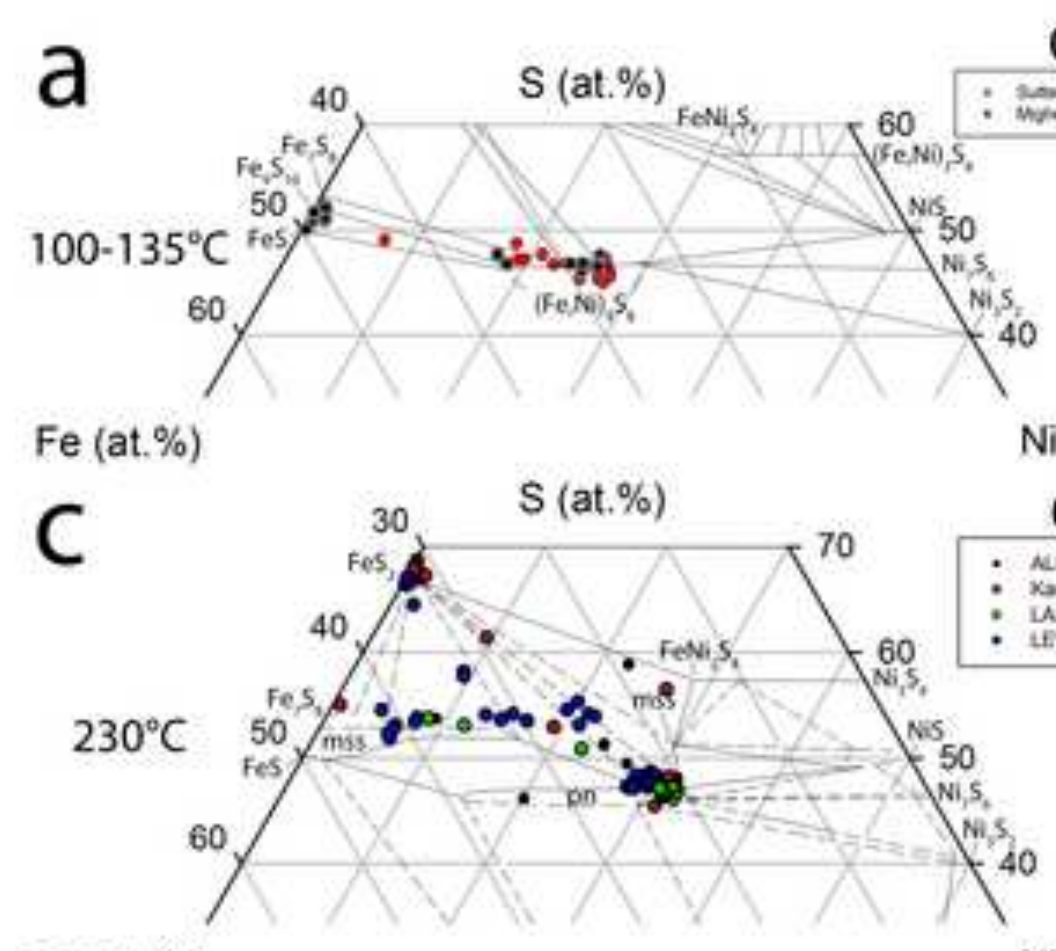

\section{CM} womenicasion

b $600^{\circ} \mathrm{C}$

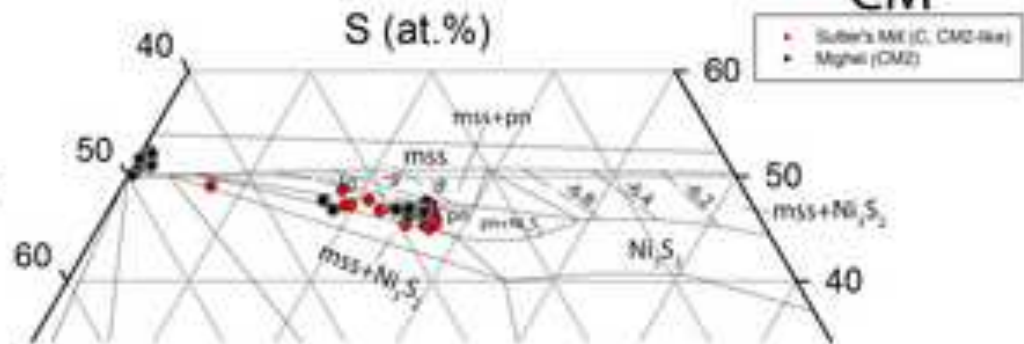

Ni (at.\%)

\section{CK}

NiHssoor (CKA) uposicas - ifwingos icos

$\mathrm{Fe}(\mathrm{at} . \%)$

Ni (at. \%)

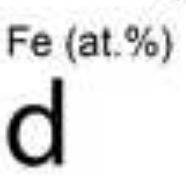

Ni (at.\%)
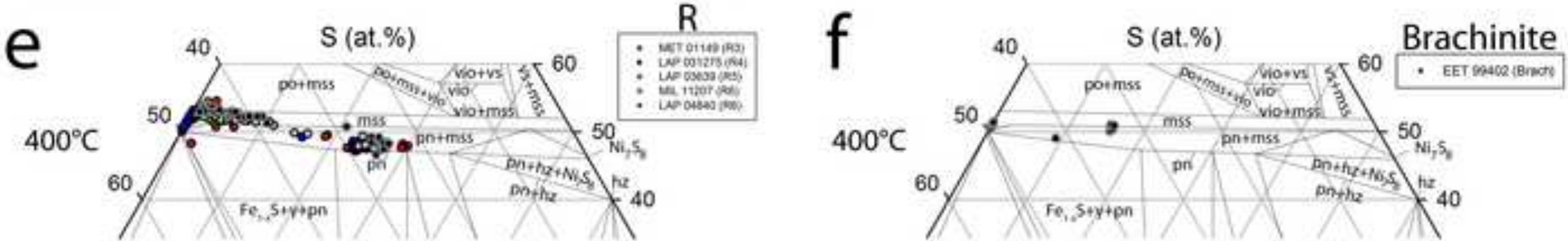

$600^{\circ} \mathrm{C}$

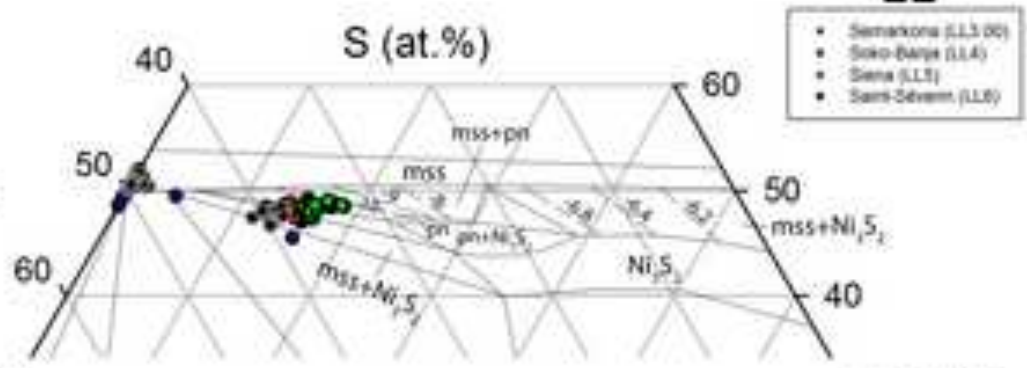

Fe (at. \%)

Ni (at.\%)

$\mathrm{Fe}(\mathrm{at} . \%)$

$\mathrm{Ni}$ (at. \%)

$\mathrm{Fe}(\mathrm{at} . \%)$

Ni (at.\%) 